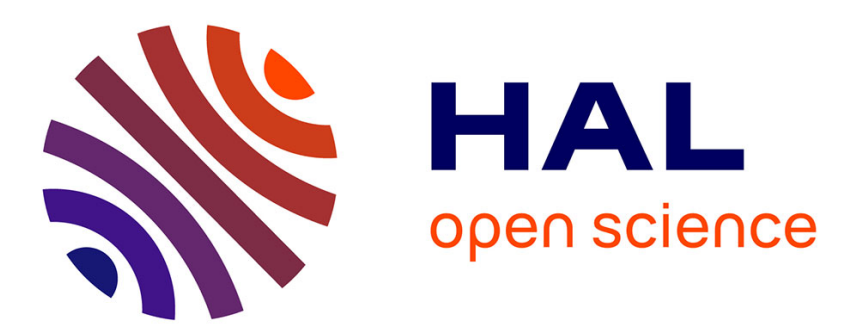

\title{
Incorporation of deep-sea and small-sized species provides new insights into gastropods phylogeny
}

Hsin Lee, Wei-Jen Chen, Nicolas Puillandre, Laetitia Aznar-Cormano, Mong-Hsun Tsai, Sarah Samadi

\section{- To cite this version:}

Hsin Lee, Wei-Jen Chen, Nicolas Puillandre, Laetitia Aznar-Cormano, Mong-Hsun Tsai, et al.. Incorporation of deep-sea and small-sized species provides new insights into gastropods phylogeny. Molecular Phylogenetics and Evolution, 2019, 135, pp.136-147. 10.1016/j.ympev.2019.03.003 . hal02560174

\section{HAL Id: hal-02560174 \\ https://hal.science/hal-02560174}

Submitted on 1 May 2020

HAL is a multi-disciplinary open access archive for the deposit and dissemination of scientific research documents, whether they are published or not. The documents may come from teaching and research institutions in France or abroad, or from public or private research centers.
L'archive ouverte pluridisciplinaire HAL, est destinée au dépôt et à la diffusion de documents scientifiques de niveau recherche, publiés ou non, émanant des établissements d'enseignement et de recherche français ou étrangers, des laboratoires publics ou privés. 


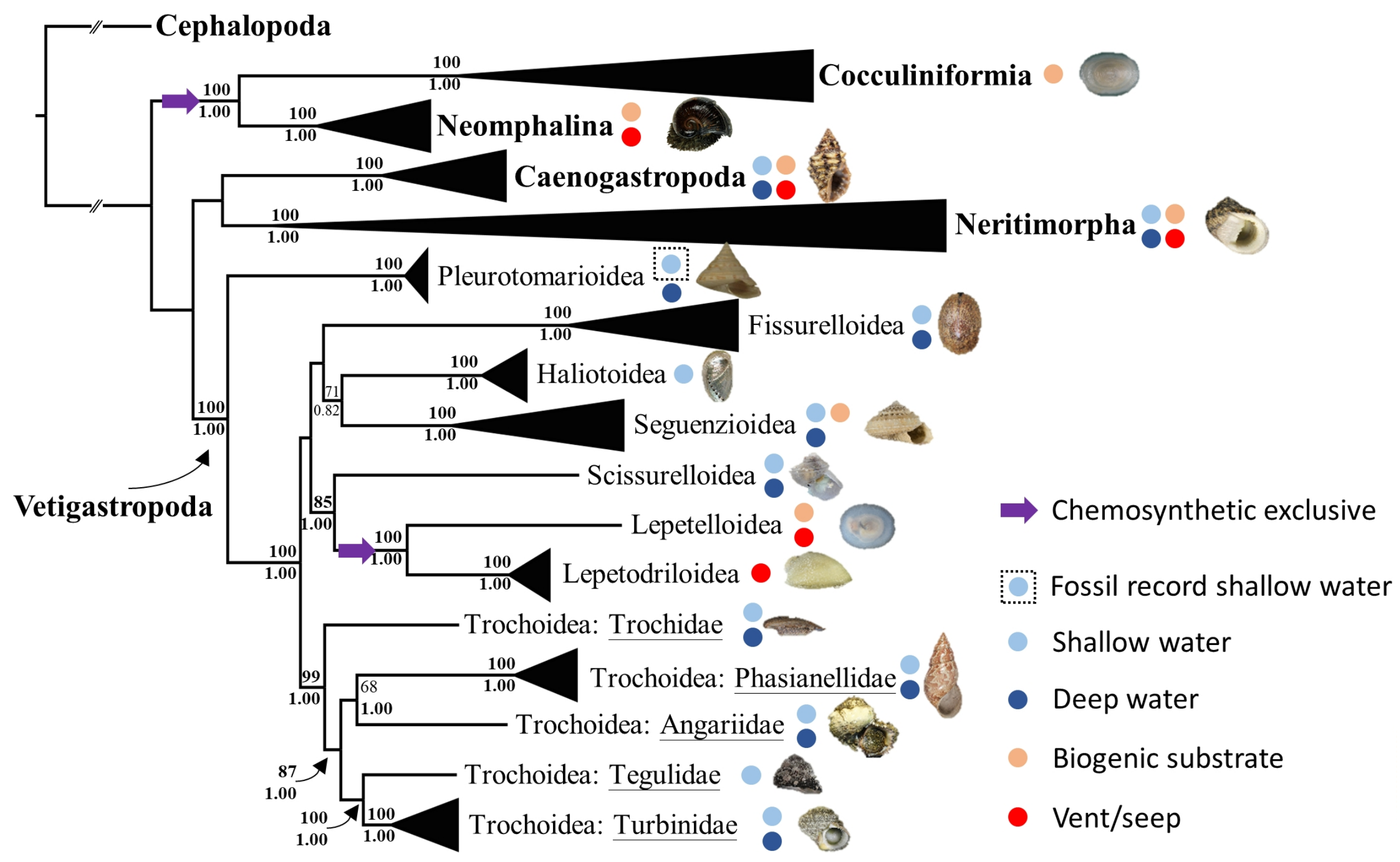


1 Incorporation of deep-sea and small-sized species provides new insights into

2 gastropods phylogeny

3 Original Research Article

4

5 Hsin Lee ${ }^{\mathrm{a}, \mathrm{b}}$, Wei-Jen Chen ${ }^{\mathrm{b} *}$, Nicolas Puillandre ${ }^{\mathrm{a}}$, Laetitia Aznar-Cormano ${ }^{\mathrm{a}}$, Mong-

6 Hsun Tsaic, Sarah Samadi ${ }^{\mathrm{a}}$

7

8 a Institut de Systématique, Evolution, Biodiversité (ISYEB), Muséum national

9 d'Histoire naturelle, CNRS, Sorbonne Université, EPHE CP 26, 57 rue Cuvier, 75005

10 Paris, France

$11{ }^{b}$ Institute of Oceanography, National Taiwan University, No. 1, Sec. 4, Roosevelt

12 Road, Taipei 10617, Taiwan

13 ' Institute of Biotechnology, National Taiwan University, No. 1, Sec. 4, Roosevelt

14 Road, Taipei 10617, Taiwan

15

16

$17 *$ Corresponding Author

18 Wei-Jen Chen

19 Room 301, Institute of Oceanography, National Taiwan University, No.1 Sec. 4

20 Roosevelt Rd, Taipei 10617, Taiwan.

21 Phone number: +886233661630

22 Fax number: +886223637062

23 E-mail address: wjchen.actinops@gmail.com 


\section{ABSTRACT}

The use of phylogeny with uneven or limited taxon sampling may bias our interpretation of organismal evolution, for instance, the origin(s) of the deep-sea animals. The Mollusca is the second most speciose phylum, in which the Gastropoda forms the largest group. However, the currently proposed hypotheses of gastropod phylogeny are mainly based on part of their taxonomic diversity, notable based on the large-sized and shallow-water species. In this study, we aimed at correcting this bias by reconstructing the phylogeny with new mitogenomes of deep-sea gastropods including Anatoma sp., Bathysciadiidae sp., Bayerotrochus teramachii, Calliotropis micraulax, Coccocrater sp., Cocculina subcompressa, Lepetodrilus guaymasensis, Peltospira smaragdina, Perotrochus caledonicus, Pseudococculinidae sp., and Shinkailepas briandi. This dataset provided the first reports of the mitogenomes for the Cocculiniformia, three vetigastropod superfamilies: Pleurotomarioidea, Lepetelloidea, and Scissurelloidea, and the neritimorph family Phenacolepadidae. The addition of deep-sea representatives also allowed us to evaluate the evolution of habitat use in gastropods. Our results showed a strongly supported sister-group relationship between the deep-sea lineages Cocculiniformia and Neomphalina. Within the Vetigastropoda, the Pleurotomarioidea was revealed as the sister-group of the remaining vetigastropods. Although this clade was presently restricted to the deep sea, fossil records showed that it has only recently invaded this habitat, thus suggesting that shallow waters was the ancestral habitat for the Vetigastropoda. The deep-sea Lepetelloidea and Lepetodriloidea formed a well-supported clade, with the Scissurelloidea sister to it, suggesting an early transition from shallow water to deep sea in this lineage. In addition, the switch between different chemosynthetic habitats 
49 was also observed in deep-sea gastropod lineages, notably in Neomphalina and

50 Lepetelloidea. In both cases, the biogenic substrates appeared as the putative ancestral

51 habitat, confirming the previously proposed hypothesis of a wooden-step to deep-sea

52 vents scenario of evolution of habitat use for these taxa.

53

54 Keywords. Deep sea; Gastropoda; Phylogeny; Mitogenome; Next Generation

55 Sequencing; Chemosynthetic environment.

56 


\section{Introduction}

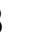

The deep sea is the most extensive ecosystem on earth, but it is yet poorly studied (Ramirez-Llodra et al., 2010). This vast area includes the water depths below the light zone ( $>200$ meters). The deep-sea floor has long been thought to be infertile (Anderson and Rice, 2006) and it is only with the great historical expeditions at the end of the $19^{\text {th }}$ century, notably the circumnavigations of the Challenger, that life was shown to be present and diverse at every depths. In the late seventies, the unexpected discovery of the hydrothermal vents revealed moreover a dense community of organisms living in very unusual environmental conditions and displaying original morphological and physiological traits (Tunnicliffe et al., 1998; Van Dover, 2000). The complete exploration of deep-sea habitats is far from being achieved (Higgs and Attrill, 2015) and other habitats such as seamounts, cold seeps or biogenic substrates have been recently explored and revealed diversified communities (Distel et al., 2000; Richer de Forges et al., 2000; Smith and Baco, 2003). Some animal lineages are restricted - or more diverse - in the deep sea but this diversity is poorly represented in the phylogenetic reconstruction of entire phyla, classes, orders or even families. The question of the evolutionary origin(s) of deep-sea organisms is thus very poorly documented.

The Mollusca is the second largest phylum in the animal kingdom, next to the Arthropoda, and the largest marine phylum (Aktipis et al., 2008). Molluscan species are found in all the marine environments, from shallow water to deep sea. The bestknown species assemblages are relatively large in size and from shallow waters.

However, these species represent only a small part of the diversity of marine mollusks (Bouchet et al., 2002, 2016). Some molluscan families and genera are less known 
because their members are tiny or they are difficult to be collected, with some groups known exclusively from the bathyal or the hadal zones (Warén, 1991, 1996; Warén and Bouchet, 1993, 2001, 2009). Massive collecting efforts, especially from the deep sea, are required to assess the magnitude of species richness, the biogeography and the phylogenetic relationships.

The Gastropoda is the largest class in the phylum Mollusca. This class comprises seven main groups: Caenogastropoda, Cocculiniformia, Heterobranchia, Neomphalina, Neritimorpha, Patellogastropoda, and Vetigastropoda. While each group contains deep-sea lineages, the members of Cocculiniformia and Neomphalina are mostly found in deep-sea habitats (Marshall, 1985; McLean, 1992; Warén and Bouchet, 1993; McLean and Harasewych, 1995; Warén, 1996; Leal and Harasewych, 1999; Warén and Bouchet, 2001; Kiel and Goedert, 2006; Heß et al., 2008; Sasaki et al., 2010; Warén, 2011). The Vetigastropoda (including abalones, slit snails, true limpets, keyhole limpets, seguenzid snails and turban snails) is the most diverse group with approximately 3,700 described living species occurring in a wide range of marine habitats from all oceans (Aktipis et al., 2008), yet it has not been exclusively studied. Among the eight superfamilies (Fissurelloidea, Haliotoidea, Lepetelloidea, Lepetodriloidea, Pleurotomarioidea, Scissurelloidea, Seguenzioidea, and Trochoidea) and the currently recognized 37 families (Bouchet et al., 2017), several are exclusively found in the deep sea (e.g., Lepetodriloidea and Seguenziidae). The Neritimorpha is supposedly a relic lineage of an early radiation with a morphological and ecological diversity equivalent to that achieved by all the other gastropods (Lindberg, 2008)

During the last decade many studies exploring the phylogenetic relationships within the Gastropoda were based on Next Generation Sequencing (NGS) techniques 
to improve the accuracy for the inference by increasing the character sampling

108 (Williams et al., 2014; Zapata et al., 2014; Osca et al., 2015; Lee et al., 2016; Uribe et al., 2016a, 2016b, 2017; Wort et al., 2017). Noteworthily, Zapata et al. (2014) reevaluated the phylogenetic relationships among the five main gastropod clades

111 (Vetigastropoda, Caenogastropoda, Heterobranchia, Neritimorpha, and

112 Patellogastropoda) by analyzing a 56-taxon matrix comprising forty new 113 transcriptomes, completed by publicly available data. This study confirmed the 114 Apogastropoda clade (Caenogastropoda + Heterobranchia) and rejected the 115 monophyletic Orthogastropoda (including all major main groups except

116 Patellogastropoda). In this latter study, Cocculiniformia and Neomphalina were 117 lacking and the rooting of the reconstructed tree remained under debate. In Aktipis 118 and Giribet (2012), the authors re-examined the phylogenetic relationships within the Vetigastropoda based on a multi-gene dataset (five genes) and a dense taxonomic sampling, which included 69 terminal taxa of the Vetigastropoda, covering all the 121 vetigastropod superfamilies and 22 out of the 37 vetigastropod families (Bouchet et 122 al., 2017). The authors of this study suggested excluding the Pleurotomarioidea and the deep-sea vetigastropod lineage Lepetelloidea from the Vetigastropoda sensu stricto. However, the relationships were not robustly resolved in this and other 125 previous studies; further investigations are required. Similarly, Uribe et al (2016b) 126 examined the relationships within the Neritimorpha based on mitogenomic 127 information, but here again deep-sea lineages were lacking. Overall, recent molecular studies investigating gastropod phylogeny and/or specific lineages such those within the Vetigastropoda focused more on the shallow water species (e.g. Zapata et al., 2014; Lee et al., 2016; Uribe et al., 2016a; Uribe et 131 al., 2016b) and used often only a few number of genetic markers (e.g., in Aktipis and 
Giribet, 2012). Deep-sea representatives were indeed only occasionally included and generally restricted to a few species or specimens (Colgan et al., 2003; Geiger and Thacker, 2005; Lee et al., 2016; Osca et al., 2015; Smith et al., 2011; Uribe et al., 2016a, 2017; Zapata et al., 2014). Such a bias in the taxonomic or character sampling may strongly distort our understanding of the causes of the observed pattern of diversity and thus of the evolution of the Gastropoda. For instance, although some phylogenetic studies included many $(>20)$ deep-sea taxa, they generally suffered from a lack of resolution on deep nodes (e.g. Kano, 2008; Aktipis and Giribet, 2012; Geiger, 2012).

In this study we reexamined the evolutionary relationships of the Gastropoda based on a dataset enriched with deep-sea gastropods from the Vetigastropoda (notably from Lepetelloidea, Scissurelloidea and Pleurotomarioidea), Cocculiniformia, Neomphalina and Neritimorpha. These taxa are rare and difficult to collect, making them the least-studied groups of gastropods. We focused on mitogenomic data that have been successfully used for resolving deep phylogenies of several gastropod groups (Grande et al., 2008; Cunha et al., 2009; Allcock et al., 2011; Medina et al., 2011; White et al., 2011; Kocot et al., 2013; Williams et al., 2014; Osca et al., 2015; Lee et al., 2016; Uribe et al., 2016a, 2016b, 2017; Wort et al., 2017) to investigate the phylogenetic relationships among deep- and shallow-water gastropods. In addition, the data from three independent nuclear gene markers, $18 S$ rRNA (18S), 28S rRNA (28S), and Histone 3 (H3), were also used as additional data for the phylogenetic hypothesis evaluation.

\section{Material and methods}

\subsection{Genomic DNA extraction}


The eleven specimens used to reconstruct mitogenomes in this study were listed in Table 1 . The specimens were mainly collected during the biodiversity expeditions under the Tropical Deep-Sea Benthos program and the cooperation project between Taiwan and France, TFDeepEvo (Table 1).

For most of the specimens, the genomic DNA was extracted using DNeasy Blood and Tissue Kit (Qiagen, Hilden, Germany) or NucleoSpin 96 Tissue kit microkit with the Eppendorf automated pipetting systems epMotion 5075 (MachereyNagel, France) following the manufacturer's protocols. For the smaller specimens (Anatoma sp. and Bathysciadiidae sp.), the genomic DNA was extracted using QIAamp DNA Micro-Kit (Qiagen, Hilden, Germany) to ensure sufficient quantity for subsequent molecular work. For Bayerotrochus teramachii, genomic DNA was extracted using a phenol-chloroform extraction method as described in Lee et al. (2016).

\subsection{Mitogenome reconstruction}

To reconstruct the mitogenome of Bayerotrochus teramachii, the long-range PCR and primer-walking Sanger sequencing were used to obtain its whole mitogenomic sequence by following the protocol described in Lee et al. (2016). Seven gastropod mitogenomes were reconstructed by using whole genome shotgun sequencing approach with NGS on Illumina platform (Table 1). The library construction and the procedure for shotgun sequencing on Illumina platform followed those described in Lee et al. (2016). The quality of the reads was checked using the program FastQC v. 0.10.1 (Andrews, 2010). Low quality reads were trimmed according to the Phred quality score $(<20)$ using the program Trimmomatic v.0.33 
Archive) database (accession number: PRJNA516567). The methods of the postsequencing assemblages of the mitogenomes followed also those described in Lee et al. (2016).

Three other gastropod mitogenomes were reconstructed by using whole genome shotgun sequencing approach with NGS on Ion Torrent platform (Table 1). Ion Torrent libraries were constructed for three other specimens by using NEB next Library preparation kit (New England Biolabs, MA, USA) for Ion Torrent. Template preparation of these libraries was performed by emulsion PCR on an Ion OneTouch robotic system, and the subsequent sequencing was performed by an Ion Torrent PGM sequencer using Hi-Q chemistry (Life technologies, France). The quality of the reads was checked by default program implemented in the sequencing analyzer and the passed reads were exported for post-sequencing assemblages.

The assemblage of mitochondrial sequence reads exported from Ion Torrent analyzer was performed using Geneious R9 assembler, in de novo mode with default settings (Biomatters Ltd., Auckland, New Zealand). Contigs with matching ends where circularized. To map their mitochondrial genes, individual gene sequences from the reference genomes of Nerita melanotragus (Castro and Colgan, 2010), Bayerotrochus teramachii (this study), and Cocculina subcompressa (this study) were used. Bait mapping was performed as follows: twenty-five iterations with assembly sensitivity set to 'med-low' (and max mismatch percentage ranging $15-20 \%$ ), without any postulate on the gene order. Individual contigs were compared and aligned to generate larger contigs.

\subsection{Mitochondrial gene annotation}


The DNA sequences of each reconstructed mitogenome were edited with sequence assembly and alignment software CodonCode Aligner v. 6.0.2 (Codoncode genetic codes for protein coding genes and default settings. Gene boundaries were

211 further determined by eye using the mitogenome of Lunella granulata as the reference 212 (Lee et al., 2016).

\subsection{Nuclear gene assemblages}

Three nuclear genes, $18 S, 28 S$, and $H 3$, were also mapped and assembled from

216 the read-pools of each NGS sample using Geneious R9 (Biomatters Ltd., Auckland, 217 New Zealand). The reference sequences for baiting and mapping were published sequences from species of the same family or superfamily as the target sample. Reference sequences were selected from the dataset of Aktipis and Giribet (2012) and retrieved from Genbank. Mapping was performed with twenty-five iterations with assembly sensitivity set to 'med-low', and max mismatch percentage $15 \%$.

\subsection{Phylogenetic inference}

\subsubsection{Datasets}

A master dataset (hereafter called 'large mt dataset') was first compiled from the

22611 newly reconstructed gastropod mitogenomes together with 43 molluscan mitogenomes retrieved from Genbank (Table 1; Supplementary table S1). The samples included 28 vetigastropods, 20 other gastropod taxa from Neritimorpha,

229 Patellogastropoda, Heterobranchia, Caenogastropoda, and Neomphalina, and 6 out230 group taxa from 4 different molluscan classes, Polyplacophora, Scaphopoda, 
231 Octopoda, and Bivalvia. The polyplacophoran Katharina tunicata was used as the distant out-group to root the inferred tree.

From this master dataset, we further compiled another mitogenomic dataset (called hereafter 'small $\mathrm{mt}$ dataset'). The data included all gastropod mitogenomes except some long-branch taxa that have been identified in the analysis with the "large mt dataset' and in several previous studies (Grande et al., 2008; Williams et al., 2014; Uribe et al., 2016a). This 46 taxa data matrix was herein used to infer the phylogeny. Octopus vulgaris (cephalopod) and Graptacme eborea (scaphopod) were chosen as distant out-groups to root the inferred tree.

A nuclear dataset was also compiled for the three targeted nuclear gene markers (18S, 28S, and $H 3)$. Using both the sequences from this study and previously published sequences, we compiled data for 45 species (Aktipis and Giribet, 2012) (Supplementary table S2).

Finally, a combined dataset of the mitochondrial sequences (from the small $\mathrm{mt}$ dataset) and the nuclear sequences was compiled by selecting the representative taxa from each superfamily or family which were from the same genus or family in both mitogenomic and nuclear gene datasets. The resulting dataset included 32 taxa (Supplementary table S3).

\subsubsection{Sequence alignment and phylogenetic analysis}

Sequences for each gene in the four compiled datasets were first aligned using the automatic multiple-alignment program MUSCLE (Edgar, 2004) and then adjusted by eye. For protein-coding genes we translated the nucleotide sequences to amino acids before aligning the sequences in order to avoid erroneous creation of gaps that would lead to shifts in the open reading frame. Each gene block was modified using 
256 Gblocks v. 0.91b (Castresana, 2000) to remove the ambiguous alignments gene-by-

257 gene, with default settings except that gap positions within the final blocks were

258 allowed. To reduce the impact of homoplasy at the third codon position sites on

259 phylogenetic inferences, RY-coding strategy was used by recoding " $A$ " and " $G$ " into

260 "R", and "C" and "T" into "Y" at the third codon positions (Chen and Mayden, 2009)

261 for each protein-coding gene. The final alignments respectively consisted of 10,393

$262 \mathrm{bp}$ for the large $\mathrm{mt}$ dataset, 11,129 bp nucleotides for the small $\mathrm{mt}$ dataset, 3,313 $\mathrm{bp}$

263 nucleotides for the nuclear dataset, and 14,442 bp nucleotides for the combined

264 dataset. Four partitions (three partitions for each codon position for mitochondrial

265 protein-coding genes and one partition for the $12 S$ plus $16 S$ rRNA genes) were set for

266 large $\mathrm{mt}$ dataset and small $\mathrm{mt}$ datasets. Five partitions were set for nuclear dataset (by

267 gene and by codon position). Finally, nine partitions were set for combined dataset

268 (Supplementary table S4).

269 Phylogenetic analyses were performed using both partitioned maximum

270 likelihood method (ML) and Bayesian inference (BI). ML was conducted by using the

271 RAxML v. 8.0 (Stamatakis, 2014) with the $G T R+G+I$ model. Nodal support was

272 assessed by bootstrapping (Felsenstein, 1985) with 1,000 pseudo-replicates. BI was

273 performed with MrBayes V. 3.2.6 (Ronquist et al., 2012) on the CIPRES Science

274 Gateway (Miller et al., 2010) with best-fit nucleotide substitution models suggested

275 by model test implemented in PartitionFinder (Lanfear et al., 2012) (Supplementary

276 table S4). Four Markov chains were performed in each of two parallel runs for

$27730,000,000$ generations for the large $\mathrm{mt}$ dataset, small $\mathrm{mt}$ dataset, and nuclear dataset,

278 and 60,000,000 generations for the combined dataset, with a sampling frequency of

279 one tree every one thousand generations. The default setting from MrBayes of the

280 burn-in value (0.25) was used. The convergence of the likelihood scores for 

all the ESS values were over 200.
284

285

286

Table

parameters was evaluated using Tracer v. 1.6 (Rambaut et al., 2014) to make sure that

\section{Results}

\subsection{Reconstructed mitogenomes and nuclear genes}

The size of the nearly complete mitogenome of Bayerotrochus teramachii, reconstructed by the primer walking and Sanger Sequencing was 13,474 bp (Table 2).

288 It contained 12 protein-coding genes, 2 rRNAs, and 11 tRNAs. Although we assembled a final contig showing overlapping sequences from the two ends of the

290 circular genome, several genes were missing $(\operatorname{trn} Y, \operatorname{trn} C, \operatorname{trn} W, \operatorname{trn} Q, \operatorname{trn} G, \operatorname{trn} E$, $291 \operatorname{cox} 3, \operatorname{trn} K, \operatorname{trn} A, \operatorname{trn} R, \operatorname{trn} N, \operatorname{trn} I$ and part of $12 S r R N A)$. These genes are commonly 292 found next to each together (e.g. in Grande et al., 2008; Cunha et al., 2009; Stöger and 293 Schrödl, 2013; Schrödl and Stöger, 2014; Williams et al., 2014; Lee et al., 2016;

294 Uribe et al., 2016a, 2016b, 2017) and we thus suspected that a hairpin of 295 mitochondrial fragment occurred during the PCR leading to skip the twisted part 296 during the elongation. Ten other new mitogenomes, yet not fully complete, were reconstructed using 298 the shotgun sequencing approach described in Lee et al (2016). After the assembly, 299 the depths of the contigs were mostly over $25 \mathrm{x}$. The amino acid sequences of each 300 contig were further examined by comparing with the reference sequences to avoid the 301 possibility of shifts in reading frames, especially for those having lower coverage.

302 Finally, for the undetermined regions, Ns were used to replace the uncertain positions.

303 We assembled each read pool into a single contig for Anatoma sp., Cocculina 304 subcompressa, Peltospira smaragdina, Bathysciadiidae sp., Shinkailepas briandi, and 305 Calliotropis micraulax. For Perotrochus caledonicus we assembled four non- 
overlapped contigs containing the mitochondrial sequences from two long segments, and from two short fragments with $n d 2$ and $n d 3$, respectively. For Coccocrater sp. we were able to assemble three contigs. From both read pools of Lepetodrilus guaymasensis and Pseudococculinidae sp., we assembled two non-overlapping final contigs. Finally, for Peltospira smaragdina, the final contig we assembled showed overlapping sequences from the two ends of the circular genome and a full set of animal mitochondrial genes.

The evolution of animal mitogenomes in terms of gene content is generally conservative. A typical animal mitogenome contains 13 protein-coding genes, 2 ribosomal RNAs, and 22 transfer RNAs; this gene content was observed in most of our reconstructed mitogenomes with a few exceptions. In the mitogenome of Cocculina subcompressa, a duplicate $\operatorname{trn} D$ was found. The $\operatorname{trn} M$ and $\operatorname{trn} Y$ could not be detected in the reconstructed mitogenome of Bathysciadiidae sp. In the reconstructed mitogenome of Pseudococculinidae sp., the $\operatorname{trn} Q, \operatorname{trn} G$, and $\operatorname{trn} E$ could not be found. Besides, a large segment could not be assembled from the read pool of Anatoma sp., containing partial $16 S r R N A$, trnV, $12 S r R N A$, and the tRNA series MYCWQGE. In the reconstructed mitogenome of Perotrochus caledonicus, the segment containing cox3, the tRNA series YCWQGE and KARNI, and one $\operatorname{trnS}$ could not be found. In the mitogenome of Shinkailepas briandi, the segment of the tRNA series MYCWQGE, trnV, and $12 S$ rRNA could not be detected. For Coccocrater sp., the segment of partial $n d 5, \operatorname{trn} H, n d 4, n d 4 l, \operatorname{trn} T$, and $\operatorname{trn} S$ could not be found. The main structures of the reconstructed mitogenomes were shown in Table 2 and the gene orders of the newly reconstructed mitogenomes were shown in Supplementary figure S1. 
For the three nuclear genes targeted in this study, sequences were assembled

331 from only four read pools. In the read pool of Bathysciadiidae sp., we assembled the 18S. In the read pool of Pseudococculinidae sp., H3 was assembled. For Perotrochus caledonicus, we assembled the $18 S$ and the $H 3$. Lastly, the $18 S$ and $28 S$ were assembled from the read pool of Shinkailepas briandi (Supplementary table S1).

\subsection{Inferred phylogenetic trees}

The topologies of the inferred ML and BI trees based on the big mt dataset were almost identical except for the position of Stomatella planulata (Supplementary figure S2), however, both positions were not supported. In these trees, Gastropoda was not monophyletic. The cephalopod (Octopus vulgaris), scaphopod (Graptacme eborea), bivalves (Pyganodon grandis, Mytilus edulis, Chlamys farreri), heterobranchs (Pupa strigosa, Peronia peronii, Siphonaria pectinata), patellogastropod (Lottia digitalis), and one neritimorph (Pleuropoma jana) were grouped together, but this clade was not meaningfully supported (bootstrap value $[\mathrm{BP}]$ below $50 \%$; posterior probability $[\mathrm{PP}]$ $=0.9$ ). This clade was placed as the sister-group of the rest (except Polyplacophora) and included the taxa of patellogastropod and bivalves with extreme long branches. We thus removed these taxa from the subsequent analyses.

Fig. 1

350

Fig. 2

Fig. 3 The phylogenetic trees inferred with respectively the small $\mathrm{mt}$, the nuclear, and the combined datasets are shown in figures 1-3 and supplementary figure S3. From all of the analyses, the Gastropoda and all the main groups within gastropods, including the Neritimorpha that was observed to be non-monophyletic in the inferred tree based on the big mt dataset (Supplementary figure S2), were resolved as monophyletic groups with mediocre or strong nodal supports. As to their inter-relationships, none

354 were well resolved with an exception for the sister-group relationship between 
355 Cocculiniformia and Neomphalina (small mt dataset: $\mathrm{BP}=100 \%, \mathrm{PP}=1.00$; nuclear 356 dataset: $\mathrm{BP}=70 \%, \mathrm{PP}=0.64$; combined dataset: $\mathrm{BP}=100 \%, \mathrm{PP}=1.00$ ).

357 Within the Vetigastropoda, the Pleurotomarioidea was inferred to be the sister358 group of the clade containing the rest of the vetigastropod superfamilies in all the 359 analyses, and this relationship was highly supported in almost all the analyses (Figs 1-

360 3). Within the latter clade, two major groups could be delimited based on the results 361 from the analyses conducted with the small $\mathrm{mt}$ and combined datasets. The first group 362 included Fissurelloidea, Seguenzioidea, Haliotoidea, Scissurelloidea, Lepetelloidea, 363 and Lepetodriloidea, whereas the second group included all the trochoidean families.

364 However, the first group was not well supported (Fig. 1 and 3). Within these two 365 major groups, some well-supported clades were resolved: the Fissurelloidea (full 366 support in all analyses), the clade containing the Haliotoidea and the Seguenzioidea 367 (small $\mathrm{mt}$ dataset: $\mathrm{BP}=87 \%, \mathrm{PP}=0.98$; combined dataset: $\mathrm{BP}=71 \%, \mathrm{PP}=1.00$ ), the 368 clade containing the Scissurelloidea, the Lepetelloidea, and the Lepetodriloidea (small 369 mt dataset: $\mathrm{BP}=92 \%, \mathrm{PP}=1.00$; combined dataset: $\mathrm{BP}=85 \%, \mathrm{PP}=1.00)$, the clade 370 grouping the Lepetelloidea and the Lepetodriloidea (full support in all analyses), and 371 the clade containing Tegulidae and Turbinidae (full support in all analyses). In the 372 analyses based on the nuclear dataset, most of the clades mentioned above were 373 found, but support values were generally weak.

\section{Discussion}

\subsection{Mitogenomic phylogeny of the Gastropoda}

The mitogenome is widely used for reconstructing the molluscan phylogeny with

378 highly conserved sizes (Stöger and Schrödl, 2013). However, mitochondrial genes

379 have generally faster evolutionary rates than nuclear genes, leaing to ambiguous 
results due to saturation when considering deep phylogenetic relationships (Burton and Barreto, 2012; Stöger and Schrödl, 2013; Wort et al., 2017). Stöger and Schrödl (2013) have suggested that long-branch attraction might provide misleading relationships in deep molluscan phylogeny. We detected such phenomenon when using the large mt dataset with some gastropod branches clustering with the longbranches of the bivalves. With this dataset, the non-monophyly observed for the Gastropoda and Neritimorpha should result from a long-branch attraction (Grande et al., 2008; Williams et al., 2014; Uribe et al., 2016a). Actually, the monophyly of the Gastropoda as well as the Neritimorpha, supported by nuclear data set (Zapata et al., 2014), was recovered when the long-branch taxa were removed (Figs. 1-3).

Another characteristic of mitogenomic datasets that should be taken into account in phylogenetic reconstructions is the absence of recombination. In fact, mitochondrial genes as a whole should be regarded as a single locus that experienced the same evolutionary history. Consequently, a particular regime of selection, different rate of evolution or introgression in a given lineage may distort the reconstructed tree. In this context, nuclear genes that are not linked to mitochondrial genes and thanks to recombination not linked among them, may be used as independent evidence to evaluate the reliability of the phylogenetic reconstruction, especially when mitochondrial introgression occurred (Chen and Mayden, 2010). In our dataset, for the well supported branches, we found congruent results between the nuclear and mitochondrial datasets (Figs 1-3).

Finally, the most critical issue that may affect phylogenetic reconstructions on gastropods is the taxonomic sampling bias. Many recent mitogenomic studies investigating the gastropod phylogeny were conducted with only shallow-water lineages (Grande et al., 2008; Cunha et al., 2009; Williams et al., 2014; Osca et al., 
2015; Uribe et al., 2016b; Wort et al., 2017) or a few deep-sea taxa (Lee et al., 2016; Uribe et al., 2016a). In Uribe et al. (2016a), the authors presented that the deep-sea Neomphalina was the sister-group of the clade containing all other gastropods sampled in the study, but this topology was considered as an artefact. In the present study, we reconstructed 11 nearly complete mitogenomes from deep-sea gastropods that included novel reports of the mitogenomes from taxa difficult to collect, such as the Cocculiniformia, Pleurotomarioidea, Scissurelloidea, and Lepetelloidea. Our results demonstrated that the two major deep-sea gastropod groups Cocculiniformia (not sampled in Uribe et al., 2016a) and Neomphalina are each monophyletic and together form a strongly supported clade (Figs 1-3), supporting the results of Aktipis and Giribet (2012). This implies that during the early diversifications of gastropods colonization of the deep sea occurred only once. The topology does not exclude the hypothesis of deep-sea origin of the entire Gastropoda or Vetigastropoda. However, this hypothesis is just unrealistic notably from a paleontological point of view. This topology is better interpreted as a transition to the deep sea occurring at the latest for the common ancestor of the Cocculiniformia and Neomphalina. Our results revealed that multiple transitions between shallow water and deep-sea habitats occurred later during the evolution of the vetigastropods (Fig. 1-3) (see discussion below).

Within the Neritimorpha, deep-sea taxa (Bathynerita, Olgasolaris and Shinkailepas) are placed in the Phenacolepadidae that, together with the Neritidae, belong to the superfamily Neritoidea. In our study Shinkailepas branches with Neritidae species, this result was congruent with the fossil records and the phylogenetic reconstruction based on partial 28S rRNA sequence (Kano et al., 2002). 
431 placement of a deep-sea lineage, the Pleurotomarioidea. It was placed as the sistergroup of the remaining vetigastropod superfamilies in most molecular studies but the support for this relationship was not robust (Colgan et al., 2003; McArthur and Harasewych, 2003; Geiger and Thacker, 2005; Williams and Ozawa, 2006; Kano, 2008; Williams et al., 2008). Aktipis and Giribet, (2012), using molecular data, even suggested excluding it from the Vetigastropoda. Conversely, several morphological analyses found it to be nested within the Vetigastropoda (Ponder and Lindberg, 1997; Sasaki, 1998). With a denser character- and taxon-sampling strategy, the hypothesis 439 of a sister-group relationship between the Pleurotomarioidea and the rest of the 440 vetigastropods is confirmed with high support values in this study. Our analyses resolve some other conflicting issues about the phylogenetic relationships and classification of the Vetigastropoda. For instance, Aktipis and Giribet (2012) suggested removing the deep-sea Lepetelloidea from Vetigastropoda sensu stricto. However, in accordance with Zapata et al. (2014), we found this superfamily to be sister to the monophyletic Lepetodriloidea that also include deep446 sea taxa. Moreover, we further identified the Scissurelloidea as the closest allies of 447 this deep-sea vetigastropod clade (Figs 1-3). This particular finding thus resolved the 448 close relationships among the Scissurelloidea, Lepetodriloidea, and Lepetelloidea. 449 Actually, no Lepetelloidea has been included in the phylogenetic studies based on 450 which a close affinity between Lepetodriloidea and Scissurelloidea was proposed 451 (Geiger and Thacker, 2005; Williams and Ozawa, 2006; Williams et al., 2008; Geiger, 452 2012). However, some studies questioned the monophyly of the Scissurelloidea and 453 found that the scissurelloid family, Anatomidae, might be sister to the 454 Lepetodriloidea, and that together these two lineages should be the sister-group of the 
other scissurelloid family, Scissurelloidea (Kano, 2008; Geiger, 2012). Our nuclear gene results showed a similar topology (Fig. 2), although the concerned nodes were not supported. The inclusion of more scissurelloid mitogenomes in the data analyses is necessary to test the hypothesis of a scissurelloid monophyly.

\subsection{Habitat use in gastropods}

To evaluate the evolutionary significance of the deep-sea habitats in gastropods, we examined the literature to evaluate the relative importance of four distinct habitats: shallow water, deep-sea floor, biogenic substrates, and hot vents and cold seeps (Fig. 4). Caenogastropoda, Neritimorpha and Vetigastropoda are present in all four habitats whereas the sister-clades Cocculiniformia and Neomphalina are mainly inhabit two deep-sea habitats (biogenic substrates, and vents and seeps), which are recognized as chemosynthetic environments.

Cocculiniform species are all restricted to biogenic substrates (Marshall, 1985; Haszprunar, 1987; McLean and Harasewych, 1995; Lesicki, 1998; Warén, 2011) whereas the members of Neomphalina can be found in both biogenic substrates (most of the species of Melanodrymiidae except those in Melanodrymia) and vents or seeps (species of Neomphalidae, and Peltospiridae) (Heß et al., 2008). The sunken wood associated species in Leptogyra and Leptogyropsis (Neomphalina, Melanodrymiidae) display putatively plesiomorphic characters in the morpho-anatomy, which led $\mathrm{He} ß$ et al. (2008) to conclude that the biogenic substrates might be the ancestral habitat of the Neomphalina. From our phylogenetic results, we found that the Neomphalina is sister to the Cocculiniformia, which suggests that the biogenic substrates might serve as an (ancestral) 'step' for the deep-sea gastropod colonization of chemosynthetic 
environments (Fig. 4), and thus support the stepping stone hypothesis (Distel et al., 2000).

In our analysis, the sister-clades Neomphalina and Cocculiniformia branches with the Vetigastropoda based on the small $\mathrm{mt}$ dataset with mediocre supports (Fig. 1). In the Vetigastropoda most lineages are present in all three types of deep-sea habitats, but only the two sister-clades Lepetelloidea and Lepetodriloidea are mainly or exclusively inhabit the deep-sea chemosynthetic environments. Two potential scenarios could be thus proposed. Either the common ancestor of Cocculiniformia, Neomphalina and Vetigastropoda was restricted to deep-sea chemosynthetic environments, and the colonization of other deep-sea habitats and shallow-waters occurred later, or conversely, the colonization toward deep-sea chemosynthetic environments occurred several time independently with two major colonization events (i.e. the common ancestor of Cocculiniformia and Neomphalina, and the common ancestor of Lepetelloidea and Lepetodriloidea).

$$
\text { Among Scissurelloidea, Lepetodriloidea, and Lepetelloidea, only one family }
$$
(Scissurellidae) mainly inhabit shallow waters $(<75 \mathrm{~m})$ (Geiger, 2012). Additional sampling of mitogenomes within Scissurelloidea is required to determine if as suggested by the nuclear gene analysis (Fig 2) and previous studies (e.g. Kano, 2008; Geiger, 2012), the Scissurellidae is the sister-group of the other deep-sea lineages from this clade. The members of the Lepetodriloidea inhabit mainly deep-sea hydrothermal vents (McLean, 1988; Sasaki et al., 2010) and most of the Lepetelloidea can be found on biogenic substrates from bathyal to hadal zones (Marshall, 1985; Haszprunar, 1987; McLean and Harasewych, 1995; Lesicki, 1998; Warén, 2011, Kano et al. 2016) and some, namely the Pyropeltidae, inhabit deep-sea vents or seeps (Sasaki et al., 2010). In addition, Kano et al. (2016) suggested that sunken wood 
habitat might be the ancestral habitat of the Lepetelloidea based on the potentially plesiomorphic radula in this superfamily, which includes species mostly associated with woods. Although additional data are still required, the available results suggest an evolution from shallow waters (Scissurellidae) to deeper habitat (Anatomidae, Lepetelloidea, Lepetodriloidea), with sunken-wood (Lepetelloidea) serving as evolutionary stepping stones to vent and seeps (Lepetodriloidea). In addition to the main deep-sea vetigastropod groups mentioned above, a few particular deep-sea lineages or species within each other vetigastropod superfamily can be found and some of them inhabit chemosynthetic environments (Fig. 4). There are, for example, some species in Cornisepta (Fissurelloidea) (Araya and Geiger, 2013) found in cold seeps (Araya and Geiger, 2013) and in hydrothermal vents (Sasaki et al., 2010), the species in Puncturella found on sunken woods (Fissurelloidea) (Warén, 2011; Pante et al., 2012) and from hydrothermal vents (Sasaki et al., 2010); most of the species attributed to Seguenziidae (Seguenzioidea) are from the deep-sea floor, and all the species of Cataegidae (Seguenzioidea) are from chemosynthetic environments (e.g. Warén and Bouchet, 2009; Olu et al., 2010; Warén, 2011). The Pleurotomarioidea were first known from the fossil records. It was thought to be one of the most ancient gastropod clades (Geiger et al., 2008). They have diversified in shallow water habitats during the Paleozoic and Mesozoic and during these periods they dominated the shallow water gastropod fauna (Harasewych, 2002). Only a single family (Pleurotomariidae) survived the Cretaceous extinction and the recent species are now restricted to bathyal depth (Harasewych, 2002). Therefore, together the position of Pleurotomariidae within Vetigastropoda and the fossil data suggest that vetigastropods originated from shallow water ancestors and that the 
colonization of deep-sea habitats, including chemosynthetic environments happened later.

Our investigation of the taxonomic literature combined with new phylogenetic results offers a first glimpse into the evolution of habitat use among gastropods. However, in each lineage, more taxa from the different habitats are required to reconstruct the ancestral states of habitat use at the major nodes in the phylogenetic tree of gastropods. Moreover, the phylogenetic relationships among and within gastropod superfamilies/families are far from being complete, especially for those groups containing the deep-sea lineages. For example, the Fissurellidae contains 55 described genera (Aktipis et al., 2011), including 7 genera restricted to the deep-sea habitats (references shown in Fig. 4) but only one was included in the recent phylogenetic study of Fissurellidae (Aktipis et al., 2011). Conversely, the scissurelloid species inhabit all kinds of marine habitats (Fig. 4) but we included so far only the deep-sea floor representative from the genus Anatoma. Mitogenomic data from other habitats and lineages are still lacking because of their very small size, these gastropods are difficult to collect and to identify, whatever the habitat. The scissureloid case emphasizes that the size of organisms is another important sampling bias in the reconstruction of the evolutionary history of the Gastropoda. Our study provides a new framework for the study of the evolution of the Gastropods by indicating the needed sampling efforts: sampling more thoroughly the deep-water habitats and the smaller organisms.

\section{Acknowledgements}

The research was mainly supported by the bilateral cooperation research funding from the Ministry of Science and Technology, Taiwan (MOST 102-2923-B-002-001- 
554 SS), and partially supported by the personal research funding from the MOST, 555 Taiwan (MOST 107-2611-M-002-007- to WJC). We thank the Institut Français in 556 Taipei and the National Taiwan University for supporting H. Lee's Ph.D. fellowship. 557 We appreciate the help from S.-P. Wu for collecting samples from Taiwan. We are 558 also grateful to A. Warén for providing the samples of L. guaymasensis and $P$. 559 smaragdina from the expeditions DIVA 1 and Alvin 2009, and the great help for 560 identifying the samples. We thank all the PIs and the participants of the expeditions 561 EXBODI, BIOPAPUA, PAPUA NIUGINI, AURORA 2007, NORFOLK 2, and 562 CONCALIS conducted by MNHN and IRD as part of the program 'Tropical Deep563 Sea Benthos'. We also thank L. Corbari for the sample collected during the BICOSE 564 cruise organized by M-A Cambon-Bonavita. We thank M. Hennion for providing the 565 images for neomphalinid and neritimorph; M. Caballer for the images of the 566 caenogastropod, seguenzioid, haliotoid, and phasianelloid; and A. Le Goff for the 567 image of the pleurotomariid; all these images were obtained under the MNHN 568 collection website (science.mnhn.fr). We thank B. Buge for the curation of specimens; 569 H.-H. Chen from M.-H. Tsai's laboratory and J. Abdelkrim and R. Debruyne from the 570 Service de Systématique Moléculaire (SSM - UMS2700) for helping in managing and 571 analyzing the NGS data; J.-N. Chen and P.-C. Lo from W.-J. Chen's laboratory and P. 572 Bouchet, V. Héros, P. Lozouet and P. Maestrati from MNHN for discussion and 573 collection management; and S. Lavoué, Y. Kano, and an anonymous reviewer for 574 discussion and for providing helpful comments on this article.

\section{Reference}


577 Aktipis, S.W., Boehm, E., Giribet, G., 2011. Another step towards understanding the

578 slit-limpets (Fissurellidae, Fissurelloidea, Vetigastropoda, Gastropoda): a

579 combined five-gene molecular phylogeny. Zoologica Scripta 40, 238-259.

580 Aktipis, S.W., Giribet, G., 2010. A phylogeny of Vetigastropoda and other

581 "archaeogastropods": re-organizing old gastropod clades. Invertebrate Biology 129, $582 \quad 220-240$.

583 Aktipis, S.W., Giribet, G., 2012. Testing relationships among the Vetigastropod taxa:

584 a molecular approach. Journal of Molluscan Studies 78, 12-27.

585 Aktipis, S.W., Giribet, G., Lindberg, D.R., Ponder, W.F., 2008. Gastropoda: an

586 overview and analysis. In: Ponder, W.F., Lindberg, D.R. (Eds.), Phylogeny and

587 Evolution of the Mollusca. University of California Press, Berkeley, California, pp. $588 \quad 201-238$.

589 Allcock, A.L., Cooke, I.R., Strugnell, J.M., 2011. What can the mitochondrial genome

590 reveal about higher-level phylogeny of the molluscan class Cephalopoda? Zool. J.

591 Linn. Soc. 161, 573-586.

592 Amon, D.J., Glover, A.G., Wiklund, H., Marsh, L., Linse, K., Rogers, A.D., Copley, 593 J.T., 2013. The discovery of a natural whale fall in the Antarctic deep sea. Deep594 Sea Research I-Topical Studies in Oceanography 92, 87-96.

595 Anderson, T. R., Rice, T., 2006. Deserts on the sea floor: Edward Forbes and his azoic 596 hypothesis for a lifeless deep ocean. Endeavour, 30, 131-137. Anseeuw, P., 597 Puillandre, N., Utge, J., Bouchet, P., 2015. Perotrochus caledonicus (Gastropoda:

598 Pleurotomariidae) revisited: descriptions of new species from the South-West 599 Pacific. European Journal of Taxonomy 134, 1-23.

600 Andrews, S., 2010. FastQC: a quality control tool for high throughput sequence data. 601 Available online at: http://www.bioinformatics.babraham.ac.uk/projects/fastqc 
Araya, J.-F., Geiger, D.L., 2013. Cornisepta guzmani new species: first species of genus confirmed from Pacific cold seep environments off central Chile (Gastropoda: Vetigastropoda: Fissurellidae). Nautilus 127, 115-118.

Bernt, M., Donath, A., Juehling, F., Externbrink, F., Florentz, C., Fritzsch, G., Puetz, J., Middendorf, M., Stadler, P.F., 2013. MITOS: Improved de novo metazoan mitochondrial genome annotation. Molecular Phylogenetics and Evolution 69, 313319.

Bolger, A.M., Lohse, M., Usadel, B., 2014. Trimmomatic: a flexible tremmer for Illumina sequence data. Bioinformatics 30, 2114-2120.

Bouchet, P., Bary, S., Héros, V., Marani, G., 2016. How many species of molluscs are there in the world's oceans, and who is going to described them? In: Héros, V., Strong, E., Bouchet, P. (Eds.), Tropical Deep-Sea Benthos Vol. 29. Mémoires du Muséum national d'Histoire naturelle, Tome 208, Paris, France, pp. 9-24.

Bouchet, P., Lozouet, P., Maestrati, P., Héros, V., 2002. Assessing the magnitude of species richness in tropical marine environments : exceptionally high numbers of molluscs at a New Caledonia site. Biological Journal of the Linnean Society 75, $421-436$.

Bouchet, P., Rocroi, J.-P., Hausdorf, B., Kaim, A., Kano, Y., Nützel, A., Parkhaev, P., Schrödl, M., Strong, E.E., 2017. Revised classification, nomenclator and typification of gastropod and monophacophoran families. Malacologia 61, 1-526. Brown, L.D., 1993. Biochemical genetics and species relationships within the genus Haliotis (Gastropoda, Haliotidae). Journal of Molluscan Studies 59, 429-443.

Burton, R.S., Barreto, F.S., 2012. A disproportionate role for mtDNA in DobzhanskyMuller incompatibilities ? Molecular Phylogenetics and Evolution 69, 313-319. 
626 Castresana, J., 2000. Selection of conserved blocks from multiple alignments for their 627 use in phylogenetic analysis. Molecular Biology and Evolution 17, 540-552.

628 Castro, L.R., Colgan, D.J., 2010. The phylogenetic position of Neritimorpha based on 629 the mitochondrial genome of Nerita melanotragus (Mollusca: Gastropoda).

630 Molecular Phylogenetics and Evolution 57, 918-923.

631 Chen, W.-J., Mayden, R.L., 2009. Molecular systematics of the Cyprinoidea 632 (Teleostei: Cypriniformes), the world's largest clade of freshwater fishes: further 633 evidence from six nuclear genes. Molecular Phylogenetics and Evolution 52, 544634549.

635 Chen, W-J., Mayden, R.L. 2010. A phylogenomic perspective on the new era of 636 ichthyology. BioScience 60, 421-432.

637 Colgan, D.J., Ponder, W.F., Beacham, E., Macaranas, J.M., 2003. Gastropod 638 phylogeny based on six segments from four genes representing coding or non639 coding and mitochondrial or nuclear DNA. Molluscan Research 23, 123-148.

640 Cunha, R.L., Grande, C., Zardoya, R., 2009. Neogastropod phylogenetic relationships 641 based on entire mitochondrial genomes. BMC Evolutionary Biology 9, 210-215.

642 Distel, D.L., Baco, A.R., Chuang, E., Morrill, W., Cavanaugh, C., Smith, C.R., 2000.

643 Marine ecology - Do mussels take wooden steps to deep-sea vents? Nature 403, $644 \quad 725-726$.

645 Edgar, R.C., 2004. MUSCLE: a multiple sequence alignment method with reduced 646 time and space complexity. Bmc Bioinformatics 5, 1-19.

647 Felsenstein, J., 1985. Confidence-limits on phylogenies - an approach using the 648 bootstrap. Evolution 39, 783-791.

649 Fretter, V., Graham, A., McLean, J., 1981. The anatomy of the Galapagos rift limpet $650 \quad$ Neomphalus fretterae. Malacologia 21, 337-361. 
651 Geiger, D.L., 2012. Monograph of the Little Slit Shells. Santa Barbara Museum of 652 Natural History, Santa Barbara, CA., USA.

653 Geiger, D.L., Thacker, C.E., 2005. Molecular phylogeny of Vetigastropoda reveals 654 non-monophyletic Scissurellidae, Trochoidea, and Fissurelloidea. Molluscan $655 \quad$ Research 25, 47-55.

656 Geiger, D.L., Nutzel, A., Sasaki, T., 2008. Vetigastropoda. In: Ponder, W.F., 657 Lindberg, D.R. (Eds.), Phylogeny and Evolution of the Mollusca. University of 658 California Press, Berkeley, CA, USA, pp. 297-330.

659 Gissi, C., Iannelli, F., Pesole, G., 2008. Evolution of the mitochondrial genome of 660 Metazoa as exemplified by comparison of congeneric species. Heredity 101, 301661320.

662 Grande, C., Templado, J., Zardoya, R., 2008. Evolution of gastropod mitochondrial 663 genome arrangements. BMC Evolutionary Biology 8, 61-75.

664 Harasewych, M.G., 2002. Pleurotomarioidean gastropods. In: Southward, A.J., Tyler, 665 P.A., Young, C.M., Fuiman, L.A. (Eds.), Advances in Marine Biology, Vol 42: 666 Molluscan Radiation - Lesser-Known Branches. Academic Press, MA, USA, pp. $667 \quad 237-294$

668 Haszprunar, G., 1987. Anatomy and affinities of cocculinid limpets (Mollusca, 669 Archaeogastropoda). Zoologica Scripta 16, 305-324.

670 Herbert, D.G., 1993. Revision of the Trochinae, tribe Trochini (Gastropoda:

671 Trochidae) of southern Africa. Annals of the Natal Museum 34, 239-308.

672 Herbert, D.G., 2012. A revision of the Chilodontidae (Gastropoda: Vetigastropoda: 673 Seguenzioidea) of southern Africa and the south-western Indian Ocean. African 674 Invertebrates 53, 381-502. 

Microanatomy, shell structre and molecular phylogeny of Leptogyra, Xyleptogyra and Leptogyropsis (Gastropoda: Neomphalida: Melanodrymiidae) from sunken wood. Journal of Molluscan Studies 74, 383-401.

679

Hickman, C.S., McLean, J.H., 1990. Systematic revision and suprageneric classification of Trochacean gastropods. Natural History Museum of Los Angeles County Science Series 35, 1-169.

Higgs, N. D., Attrill, M., 2015. Biases in biodiversity: wide-ranging species are discovered first in the deep sea. Frontiers in Marine Science 2, 61.

Kano, Y., Chiba, S., Kase, T., 2002. Major adaptive radiation in neritopsine gastropods estimated from 28S rRNA sequences and fossil records. Proceedings of the Royal Society B-Biological Sciences 269, 2456-2465.

Kano, Y., 2008. Vetigastropod phylogeny and a new concept of Seguenzioidea: independent evolution of copulatory organs in the deep-sea habitats. Zoologica Scripta $37,1-21$.

Kano, Y., Chikyu, E., Warén, A., 2009. Morphological, ecological and molecular characterization of the enigmatic planispiral snail genus Adeuomphalus (Vetigastropoda: Seguenzioidea). Journal of Molluscan Studies 75, 397-418.

Kano, Y., Fukumori, H., Brenzinger, B., Warén, A., 2013. Driftwood as a vector for the oceanic dispersal of estuarine gastropods (Neritidae) and an evolutionary pathway to the sunken-wood community. Journal of Molluscan Studies 79, 378382.

Kano, Y., Takano, T., Schwabe, E., Warén, A., 2016. Phylogenetic position and systematics of the wood-associate limpet genus Caymanabyssia and implications 

for ecological radiation into deep-sea organic substrates by lepetelloid gastropods. Marine Ecology - An Evolutionary Perspective 37, 1116-1130.

701 Kiel, S., Goedert, J.L., 2006. Deep-sea food bonanzas: early Cenozoic whale-fall 702 communities resemble wood-fall rather than seep comminities. Proceedings of the 703 Royal Society B-Biological Sciences 273, 2625-2631.

704 Knight, J.B., Cox, L.R., Keen, A.M., Battern, R.L., Yochelson, E.L., Robertson, R. 705 1960. Archeaogastropoda and some (mainly Paleozoic) Caenogastropoda and 706 Opisthobranchia (Mollusca: Gastropoda). In: Moore, R.C. (Ed.), Treatise on 707 invertebrate paleontology. Part I: Mollusca 1. Geological Society of America and $708 \quad$ Kansas University Press, Lawrence, Kansas, USA, pp. 1-351.

709 Kocot, K.M., Halanych, K.M., Krug, P.J., 2013. Phylogenomics supports

710 Panpulmonata: Opisthobranch paraphyly and key evolutionary steps in a major 711 radiation of gastropod molluscs. Molecular Phylogenetics and Evolution 69, 764712771.

713 Lanfear, R., Calcott, B., Ho, S.Y.W., Guindon, S., 2012. PartitionFinder: combined 714 selection of partitioning schemes and substitution models for phylogenetic 715 analyses. Molecular Biology and Evolution 29, 1695 - 1701.

716 Leal, J.H., Harasewych, M.G., 1999. Deepest Atlantic molluscs: hadal limpets 717 (Mollusca, Gastropoda, Cocculiniformia) from the northern boundary of the 718 Caribbean Plate. Invertebrate Biology 118, 116-136.

719 Lee, H., Samadi, S., Puillandre, N., Tsai, M.-H., Dai, C.-F., Chen, W.-J., 2016. Eight 720 new mitogenomes for exploring the phylogeny and classification of 721 Vetigastropoda. Journal of Molluscan Studies 82, 534-541. 
Lesicki, A., 1998. Checklist of gastropod species refereed to the order Cocculinidormia Haszprunar, 1987 (Gastropoda: Cocculinoidea et Lepetelloidea) with some remarks on their food preferences. Folia Malacologica 6, 47-62.

Lindberg, D.R., 2008. Patellogastropoda, Neritimorpha, and Cocculinoidea. In: Ponder, W.F., Lindberg, D.R. (Eds.), Phylogeny and Evolution of the Mollusca. University of California Press, Berkeley, California, USA, pp. 271-296.

Marshall, B.A., 1985. Recent and Tertiary Cocculinidae and Pseudococculinidae (Mollusca, Gastropoda) from New-zealand and New-south-wales. New Zealand Journal of Zoology 12, 505-546.

Marshall, B.A., 1996. A new subfamily of the Addisoniidae associated with cephalopod beaks from the tropical southwest Pacific, and a new pseudococculinid associated with chondrichthyan egg cases from New Zealand (Mollusca: Lepetelloidea). Veliger 39, 250-259.

Maynard, B.T., Kerr, L.J., McKiernan, J.M., Jansen, E.S., Hanna, P.J., 2005. Mitochondrial DNA sequence and gene organization in Australian backup abalone Haliotis rubra (Leach). Marine Biotechnology 7, 645-658.

McArthur, A.G., Harasewych, M.G., 2003. Molecular systematics of the major lineages of the Gastropoda. In: Lydeard, C., Lindberg, D.R. (Eds.), Molecular Systematics and Phylogeography of Mollusks. Smithonian Institute, WA, USA, pp. 140-160.

McLean, J.H., 1988. New archaeogastropod limpets from hydrothermal vents: superfamily Lepetodrilacea I. Systematic Descriptions. Philosophical Transactions of the Royal Society of London. Series B, Biological Sciences 319, 1-32. 
McLean, J.H., 1992. Cocculiniform limpets (Cocculinidae and Pyropeltidae) living on whale bone in the deep-sea off California. Journal of Molluscan Studies 58, 401414.

McLean, J.H., Geiger, D.L., 1998. New Genera and Species having the fissurisepta shell form, with a generic-level phylogenetic analysis (Gastropoda: Fissurellidae). Contributions in Science 475, 1-32.

McLean, J.H., Harasewych, M.G., 1995. Review of western Atlantic species of cocculinid and pseudococculinid limpets, with descriptions of new species (Gastropoda: Cocculiniformia). Contributions in Science (Los Angeles) 453, 1-33.

Medina, M., Lal, S., Valles, Y., Takaoka, T.L., Dayrat, B.A., Boore, J.L., Gosliner, T., 2011. Crawling through time: Transition of snails to slugs dating back to the Paleozoic, based on mitochondrial phylogenomics. Marine Genomics 4, 51-59.

Miller, M.A., Pfeiffer, W., Schwartz, T., 2010. Creating the CIPRES Science Gateway fir inference of large phylogenetic trees. Gateway Computing Environments Workshop (GCE), New Orleans, LA, USA, pp. 1-8.

Olu, K., Cordes, E.E., Fisher, C.R., Brooks, J.M., Sibuet, M., Desbruyeres, D., 2010. Biogeography and Potential Exchanges Among the Atlantic Equatorial Belt ColdSeep Faunas. Plos One 5, e11967.

Osca, D., Templado, J., Zardoya, R., 2015. Caenogastropod mitogenomics. Molecular Phylogenetics and Evolution 93, 118-128.

Pante, E., Corbari, L., Thubaut, J., Chan, T.-Y., Mana, R., Boisselier, M.-C., Bouchet, P., Samadi, S., 2012. Exploration of the Deep-Sea Fauna of Papua New Guinea. Oceanography $25,214-225$.

Ponder, W.F., Colgan, D.J., Healy, J.M., Nützel, A., Simone, L.R.L., Strong, E.E., 2008. Caenogastropoda. In: Ponder, W.F., Lindberg, D.R. (Eds.), Phylogeny and 

331-384.

772 Ponder, W.F., Lindberg, D.R., 1997. Towards a phylogeny of gastropod molluscs:

773 Analysis using morphological characters. Zoological Journal of the Linnean

774 Society $119,83-265$.

775 Rambaut, A., 1996. Se-al: Sequence alignment editor version 1.0 a1. Department of Zoology, University of Oxford, Oxford.

777 Rambaut, A., Suchard, M.A., Xie, D., Drummond, A.J., 2014. Tracer v1.6, Available 778 from http://beast.bio.ed.ac.uk/Tracer.

779 Ramirez-Llodra, E., Brandt, A., Danovaro, R., De Mol, B., Escobar, E., German, C., 780 Levin, L.A., Arbizu, P.M., Menot, L., Buhl-Mortensen, P., Narayanaswamy, B.E., 781 Smith, C.R., Tittensor, D.P., Tyler, P.A., Vanreusel, A., Vecchione, M., 2010. 782 Deep, diverse and definitely different: unique attributes of the world's largest 783 ecosystem. Biogeosciences, 7, 2851-2899.

784 Richer de Forges, B., Koslow, J.A., Poore, G.C.B., 2000. Diversity and endemism of 785 the benthic seamount fauna in the southwest Pacific. Nature 405, 944-947.

786 Ronquist, F., Teslenko, M., van der Mark, P., Ayres, D.L., Darling, A., Hohna, S.,

787 Larget, B., Liu, L., Suchard, M.A., Huelsenbeck, J.P., 2012. MrBayes 3.2:

788 Efficient Bayesian Phylogenetic Inference and Model Choice Across a Large 789 Model Space. Systematic Biology 61, 539-542.

790 Rosenberg, G., Moretzsohn, F., Garcia, E.F., 2009. Gastropoda (Mollusca) of the Gulf 791 of Mexico. Texas A\&M University Press, TA, USA, pp. 579-699.

792 Sasaki, T., 1998. Comparative anatomy and phylogeny of teh recent 793 Archaeogastropoda (Mollusca: Gastropoda). The University of Tokyo Bulletin 38, $794 \quad 1-223$. 
Sasaki, T., Warén, A., Kano, Y., Okutani, T., Fujikura, K., 2010. Gastropods from Recent hot vents and cold seeps: systematics, diversity and life strategies. Topics in Geobiology, Springer, the Netherlands, pp. 169-254.

798

Schrödl, M., Stöger, I., 2014. A review on deep molluscan phylogeny: old markers, 799 integrative approaches, persistent problems. Journal of Natural History 48, 2773 $800 \quad 2804$.

801 Smith, C.R., Baco, A.R., 2003. Ecology of whale falls at the deep-sea floor. In:

802 Gibson, R.N., Atkinson, R.J.A. (Eds.), Oceanography and Marine Biology, Vol 41, 803 pp. $311-354$.

804 Smith, S.A., Wilson, N.G., Goetz, F.E., Feehery, C., Andrade, S.C.S., Rouse, G.W., 805 Giribet, G., Dunn, C.W., 2011. Resolving the evolutionary relationships of 806 molluscs with phylogenomic tools. Nature 480, 364-369.

807 Stamatakis, A., 2014. RAxML version 8: a tool for phylogenetic analysis and post808 analysis of large phylogenies. Bioinformatics 30, 1312-1313.

809 Stöger, I., Schrödl, M., 2013. Mitogenomics does not resolve deep molluscan 810 relationships (yet?). Molecular Phylogenetics and Evolution 69, 376-392.

811 Tunnicliffe, V., McArthur, A.G., McHugh, D., 1998. A biogeographical perspective 812 of the deep-sea hydrothermal vent fauna. Advances in Marine Biology 34, 353813442.

814 Uribe, J.E., Kano, Y., Templado, J., Zardoya, R., 2016a. Mitogenomics of 815 Vetigastropoda: insights into the evolution of pallial symmetry. Zoologica Scripta $816 \quad 45,145-159$.

817 Uribe, J.E., Colgan, D., Castro, L.R., Kano, Y., Zardoya, R., 2016b. Phylogenetic 818 relationships among superfamilies of Neritimorpha (Mollusca: Gastropoda). 819 Molecular Phylogenetic and Evolution 104, 21-31. 
Uribe, J.E., Williams, S.T., Templado, J., Abalde, S., Zardoya, R., 2017. Denser mitogenomic sampling improves resolution of the phylogeny of the superfamily Trochoidea (Gastropoda: Vetigastropoda). Journal of Molluscan Studies 83, 111118.

Van Dover, C.L., 2000. The Ecology of Deep-Sea Hydrothermal Vents. Princeton University Press, Princeton, NJ, USA.

Warén, A., 1991. New and little known skeneimorph gastropods from the Mediterranean Sea and the adjacent Atlantic Ocean. Bollettino Malacologico 27, 149-247.

Warén, A., 1996. Description of Bathysciadium xylophagum Warén and Carrozza, sp.n. and comments on Addisonia excentrica (Tiberi) two Mediterranean cocculiniform gastropods. Bollettino Malacologico 31, 231-266.

Warén, A., 2011. Molluscs on biogenic substrates. In : Bouchet, P., Le Guyader, H., Pascal, O. (Eds), The Natural History of Santo. Museum National d'Histoire Naturelle, Paris; IRD, Marseille; Pro-Natura international, Paris, pp. 438-448.

Warén, A., Bengtson, S., Goffredi, S.K., Van Dover, C.L., 2003. A hot-vent gastropod with iron sulfide dermal sclerites. Science 302, 1007-1007.

Warén, A., Bouchet, P., 1993. New records, species, genera, and a new family of gastropods from hydrothermal vents and hydrocarbon seeps. Zoologica Scripta 22, $1-90$

Warén, A., Bouchet, P., 2001. Gastropoda and Monoplacophora from hydrothermal vents and seeps; New taxa and records. Veliger 44, 116-231.

Warén, A., Bouchet, P., 2009. New gastropods from deep-sea hydrocarbon seeps off West Africa. Deep-Sea Research II 56, 2326-2349. 
844 White, T.R., Conrad, M.M., Tseng, R., Balayan, S., Golding, R., de Frias Martins, 845 A.M., Dayrat, B.A., 2011. Ten new complete mitochondrial genomes of 846 pulmonates (Mollusca: Gastropoda) and their impact on phylogenetic relationships. 847 Bmc Evolutionary Biology 11, 295-309.

848 Williams, S.T., 2012. Advances in molecular systematics of the vetigastropod 849 superfamily Trochoidea. Zoologica Scripta 41, 571-595.

850 Williams, S.T., Donald, K.M., Spencer, H.G., Nakano, T., 2010. Molecular 851 systematics of the marine gastropod families Trochidae and Calliostomatidae 852 (Mollusca: Superfamily Trochoidea). Molecular Phylogenetics and Evolution 54, $853 \quad 783-809$.

854 Williams, S.T., Foster, P.G., Littlewood, D.T.J., 2014. The complete mitochondrial 855 genome of a turbinid vetigastropod from MiSeq Illumina sequencing of genomic 856 DNA and steps towards a resolved gastropod phylogeny. Gene 533, 38-47.

857 Williams, S.T., Karube, S., Ozawa, T., 2008. Molecular systematics of 858 Vetigastropoda : Trochidae, turbinidae and trochoidea redefined. Zoologica Scripta $859 \quad 37,483-506$.

860 Williams, S.T., Ozawa, T., 2006. Molecular phylogeny suggests polyphyly of both the 861 turban shells (family Turbinidae) and the superfamily Trochoidea (Mollusca :

862 Vetigastropoda). Molecular Phylogenetics and Evolution 39, 33-51.

863 Wort, E.J.G., Fenberg, P.B., Williams, S.T., 2017. Testing the contribution of 864 individual genes in mitochondrial genomes for assessing phylogenetic relationships 865 in Vetigastropoda. Journal of Molluscan Studies 83, 123-128.

866 Zapata, F., Wilson, N.G., Howison, M., Andrade, S.C.S., Joerger, K.M., Schroedl, M., 867 Goetz, F.E., Giribet, G., Dunn, C.W., 2014. Phylogenomic analyses of deep 
868 gastropod relationships reject Orthogastropoda. Proceedings of the Royal Society

869 B-Biological Sciences 281, 20141739.

870 


\section{Figure captions}

Figure 1. Phylogenetic relationships of the Gastropoda inferred using partitioned maximum-likelihood (ML) methods based on 11,129 bp nucleotide sequences combined from 13 mitochondrial protein-coding genes and 2 ribosomal RNA genes (small mt dataset). Nodal supports are shown as bootstrap (BP) values in percentage (above) and posterior probabilities (PP) (below). Values below $50 \%$ in BP and 0.8 in PP are not shown. Values higher than $80 \%$ in BP and 0.95 in PP are considered significant and shown in bold. Taxa names in bold represent the deep-sea lineages.

Figure 2. Phylogenetic tree reconstructed using the partitioned maximum-likelihood (ML) methods based on 3,313 bp nucleotide sequences combined from $18 S, 28 S$, and H3 (nuclear dataset). Numbers above/below the nodes are bootstrap (BP) values in percentage / posterior probabilities (PP). Values within superfamily and values below $50 \%(\mathrm{BP})$ and $0.8(\mathrm{PP})$ are not shown. Values higher than $80 \%(\mathrm{BP})$ and $0.95(\mathrm{PP})$ are shown in bold. Asterisk indicates the superfamilies not found monophyletic in the tree.

Figure 3. Partitioned maximum-likelihood (ML) tree based on 14,442 bp nucleotide sequences combined from 13 mitochondrial protein-coding genes, 2 ribosomal RNA genes, and nuclear genes including $18 S, 28 S$, and $H 3$ (combined dataset). Nodal supports are shown as bootstrap (BP) values in percentage / posterior probability (PP). Values below 50\% in BP and 0.8 in PP are not shown. Values higher than $80 \%$ in BP and 0.95 in PP are considered significant and shown in bold. Taxa from Cocculiniformia, Neomphalina, Caenogastropoda, Neritimorpha, and from the same vetigastropod superfamily or family are collapsed. The uncollapsed tree is shown in supplementary figure S3. 
896 Figure 4. On the left: a simplified phylogeny modified from the inferred tree based on 897 the combined gene dataset shown in Fig. 3. The nodes with support values below $75 \%$ 898 (BP) are collapped and shown as polytomies. Main gastropod groups are shown in 899 bold. The family-rank taxa are underlined. The red arrows indicate the two major 900 events of habitat switch. On the middle: the habitats for each taxon. Four distinct 901 habitats are described: shallow water, deep-sea floor, biogenic substrate, and vent \& 902 seep. The colored-circle represents the taxon presents majorly in the habitat. If there is 903 only a single or several species in a single genus that are present in one habitat, 904 'minor' is ploted under the habitat. On the right: the references of the taxon record. 
Table 1. New gastropod mitogenomes assembled in this study. MNHN: Muséum National d'Histoire Naturelle. NTUM: National

Taiwan University Museums. The corresponding field data of the specimens from MNHN are found at https://expeditions.mnhn.fr/

\begin{tabular}{|c|c|c|c|c|c|c|}
\hline & Species & Voucher number & mitogenome & Sequencing method & Expedition, station, and locality (depth) & Habitat \\
\hline \multicolumn{7}{|l|}{$\begin{array}{c}\text { Cocculiniformia, } \\
\text { Cocculinoidea }\end{array}$} \\
\hline Bathysciadiidae & Bathysciadiidae sp. & MNHN-IM-2013-40843 & MH837532 & NGS, Illumina & $\begin{array}{l}\text { EXBOBI, CP3791, Canal de la Havannah, New } \\
\text { Caledonia (806m) }\end{array}$ & cephalopod beak \\
\hline Cocculinidae & Cocculina subcompressa & MNHN-IM-2013-40775 & MH837536 & NGS, Illumina & $\begin{array}{l}\text { BIOPAPUA, CP3645, Huon Gulf, Papua New Guinea } \\
(410 \mathrm{~m})\end{array}$ & sunken wood \\
\hline Cocculinidae & Coccocrater sp. & MNHN-IM-2013-41044 & MH837535 & NGS, Iron Torrent & $\begin{array}{l}\text { PAPUA NIUGINI, CP3967, Sek Island, Papua New } \\
\text { Guinea (980m) }\end{array}$ & sunken wood \\
\hline \multicolumn{7}{|l|}{ Neomphalina, } \\
\hline \multicolumn{7}{|l|}{ Neomphaloidea } \\
\hline Peltospiridae & Peltospira smaragdina & NTUM-Inv-00001 & MH837538 & NGS, Illumina & $\begin{array}{l}\text { DIVA 1, DV09, Lucky Strike vent, Mid-Atlantic Ridge } \\
(1653 \mathrm{~m})\end{array}$ & hydrothermal vent \\
\hline \multicolumn{7}{|l|}{ Neritimorpha, } \\
\hline \multicolumn{7}{|l|}{ Neritoidea } \\
\hline Phenacolepadidae & Shinkailepas briandi & MNHN-IM-2013-41914 & MH837541 & NGS, Iron Torrent & $\begin{array}{l}\text { BISCOSE 1, PL568 ASPI2, Snake Pit, Mid-Atlantic } \\
\text { Ridge (3466m) }\end{array}$ & hydrothermal vent \\
\hline \multicolumn{6}{|l|}{ Vetigastropoda, } & Lepetelloidea \\
\hline Lepetodrilidae & Lepetodrilus guaymasensis & NTUM-Inv-00002 & MH837537 & NGS, Illumina & $\begin{array}{l}\text { Alvin 2009, AT } 15-59 \text { sta. dive } 4590 \text {, Off Punta } \\
\text { Arenas, Costa Rica }(1800 \mathrm{~m})\end{array}$ & methane seep \\
\hline \multicolumn{7}{|l|}{ Pleurotomarioidea } \\
\hline Pleurotomariidae & Bayerotrochus teramachii & N/A & MH837533 & LR-PCR & North-East of Taiwan (unknown) & dee-sea floor \\
\hline Pleurotomariidae & Perotrochus caledonicus & MNHN-IM-2009-7483 & MH837539 & NGS, Iron Torrent & $\begin{array}{l}\text { NORFOLK 2, DW2156, Ile des Pins, New Caledonia } \\
(484 \mathrm{~m})\end{array}$ & dee-sea floor \\
\hline \multicolumn{7}{|l|}{ Scissurelloidea } \\
\hline Anatomidae & Anatoma sp. & MNHN-IM-2013-42003 & MH837531 & NGS, Illumina & $\begin{array}{l}\text { CONCALIS, DW3025, Grand Passage, New Caledonia } \\
(398 \mathrm{~m})\end{array}$ & dee-sea floor \\
\hline \multicolumn{7}{|l|}{ Seguenzioidea } \\
\hline Calliotropidae & Calliotropis micraulax & MNHN-IM-2009-31774 & MH837534 & NGS, Illumina & $\begin{array}{l}\text { EXBODI, CP3842, Passe de la Sarcelle, New } \\
\text { Caledonia }(763 \mathrm{~m})\end{array}$ & dee-sea floor \\
\hline
\end{tabular}


Table 2. Summary of features of the new gastropod mitogenomes, including total size of the genome (bp), percentage of A and T (AT

$\%)$, and the sizes of protein-coding genes (bp).

\begin{tabular}{|c|c|c|c|c|c|c|c|c|c|c|c|}
\hline & $\begin{array}{l}\text { Anatoma } \\
\text { sp. }\end{array}$ & $\begin{array}{l}\text { Bathysciadiid } \\
\text { ae sp. }\end{array}$ & $\begin{array}{l}\text { Calliotropis } \\
\text { micraulax }\end{array}$ & $\begin{array}{l}\text { Coccocrater } \\
\text { sp. }\end{array}$ & $\begin{array}{l}\text { Cocculina } \\
\text { subcompressa }\end{array}$ & $\begin{array}{l}\text { Lepetodrilus } \\
\text { guaymasensis }\end{array}$ & $\begin{array}{l}\text { Bayerotrochu } \\
\text { s teramachii }\end{array}$ & $\begin{array}{l}\text { Peltospira } \\
\text { smaragdina }\end{array}$ & $\begin{array}{l}\text { Perotrochus } \\
\text { caledonicus }\end{array}$ & $\begin{array}{l}\text { Pseudococculinid } \\
\text { ae sp. }\end{array}$ & $\begin{array}{l}\begin{array}{l}\text { Shinkailepas } \\
\text { briandi }\end{array} \\
\end{array}$ \\
\hline size & 13,568 & 17,138 & 17,040 & 13,783 & 18,067 & 17,060 & 13,473 & 15,112 & 13,782 & 15,380 & 13,618 \\
\hline AT\% & 61.0 & 63.9 & 63.3 & 65.8 & 70.6 & 63.4 & 63.6 & 69.4 & 60.0 & 72.0 & 61.7 \\
\hline $\operatorname{cox} 1$ & 1,548 & 1,539 & 1,554 & 1,533 & 1,542 & 1,545 & 1,536 & 1,542 & $1,536^{\mathrm{b}}$ & 1,548 & 1,548 \\
\hline $\cos 2$ & 699 & 684 & 684 & 690 & 690 & 708 & 693 & 702 & 702 & 711 & 690 \\
\hline $\operatorname{cox} 3$ & 780 & 774 & 780 & 780 & 780 & 780 & $-a$ & 780 & $-a$ & 774 & 780 \\
\hline atp6 & 633 & 504 & $309^{b}$ & 579 & 717 & 714 & 696 & 678 & 696 & 495 & 696 \\
\hline atp8 & 165 & 339 & 207 & 225 & 249 & 222 & 174 & 162 & 174 & 231 & 165 \\
\hline cytb & 1,137 & 1,149 & 1,164 & $348^{\mathrm{b}}$ & 1,137 & 1,137 & 1,140 & 1,140 & 1,140 & 1,137 & 1,137 \\
\hline$n d 1$ & 945 & 948 & 1,002 & $852^{\mathrm{b}}$ & 948 & 939 & 921 & 948 & 936 & 951 & 933 \\
\hline$n d 2$ & 1,086 & 1,038 & 1,095 & 1,116 & 1,119 & 1,089 & 1,059 & 1,095 & 1,099 & 1,002 & 1,131 \\
\hline$n d 3$ & 354 & 357 & 354 & 354 & 372 & 351 & 354 & 381 & $323^{b}$ & 354 & 354 \\
\hline nd4 & 1,347 & 1,344 & 1,302 & $-\mathrm{a}$ & 1,359 & 1,386 & 1,305 & 1,227 & $1,324^{b}$ & 1,383 & 1,398 \\
\hline nd4l & 300 & 285 & 297 & $-\mathrm{a}$ & 300 & 300 & 276 & 300 & 297 & 303 & 297 \\
\hline nd5 & 1,737 & 1,743 & 1,746 & $1,351^{b}$ & 1,725 & 1,734 & 1,784 & 1,701 & 1,731 & 1,701 & 1,716 \\
\hline nd6 & 489 & 525 & 510 & 495 & 516 & 519 & 507 & 498 & 507 & 504 & 507 \\
\hline
\end{tabular}

a: gene could not be sequenced; b: incomplete sequence 


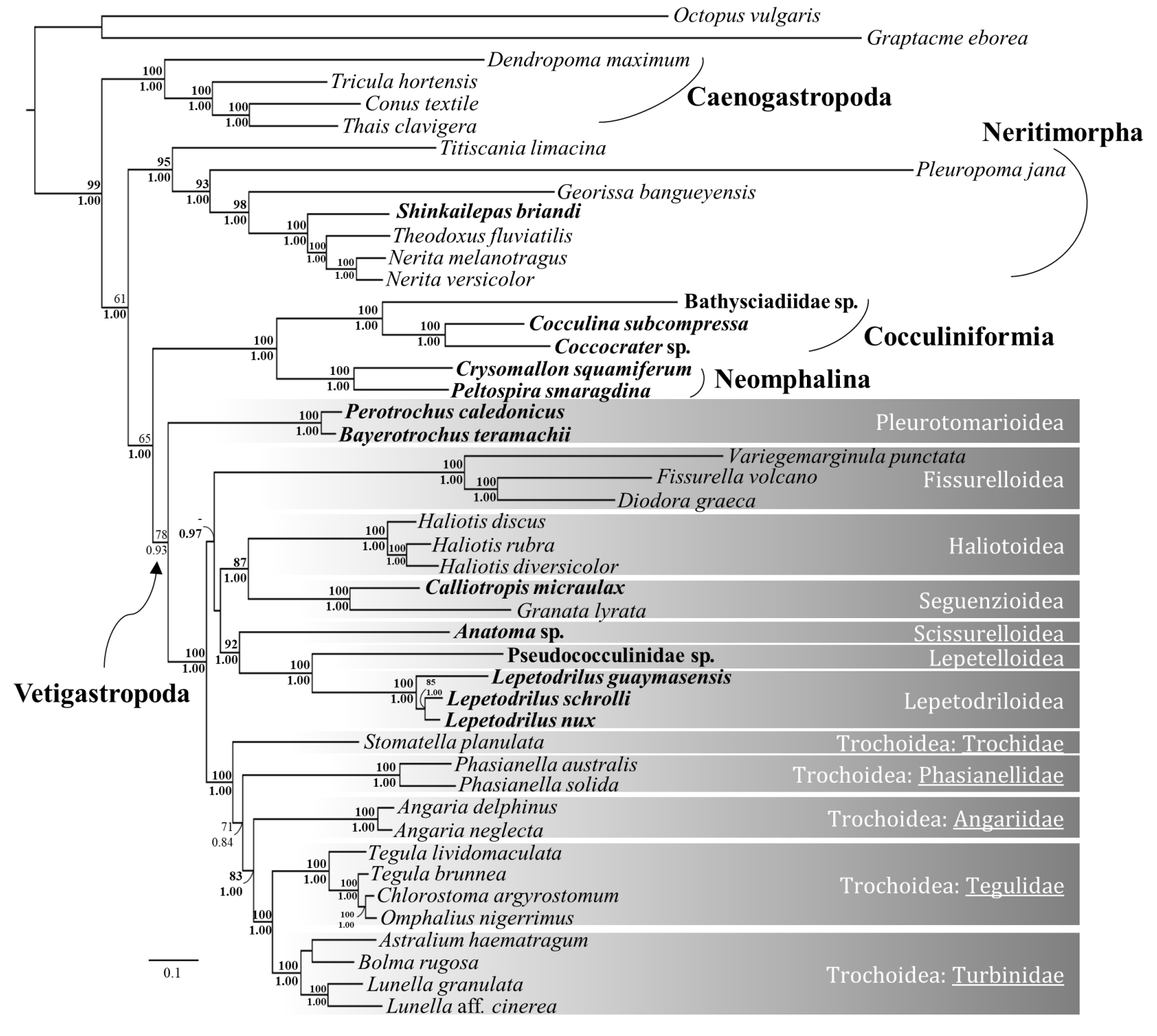




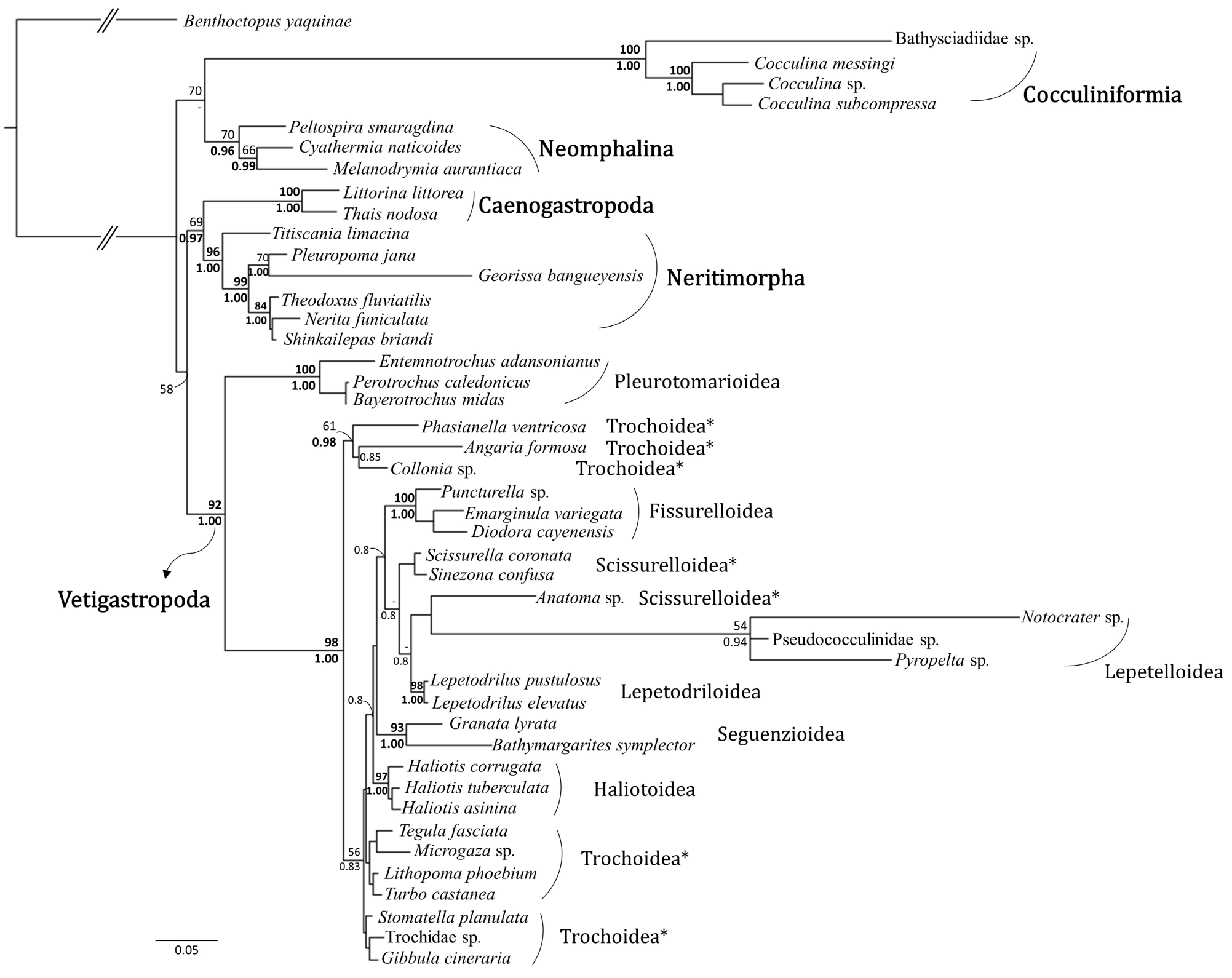




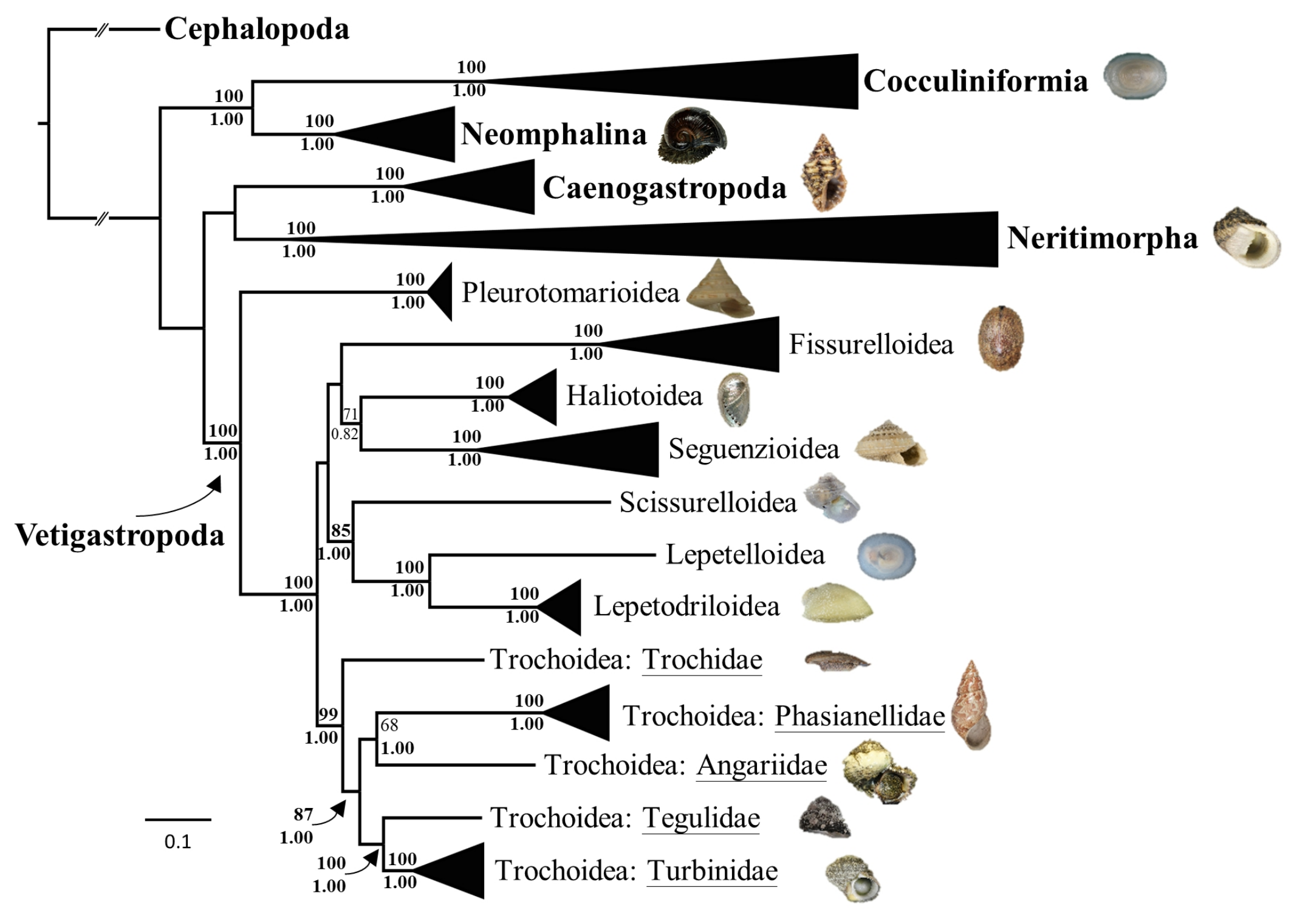




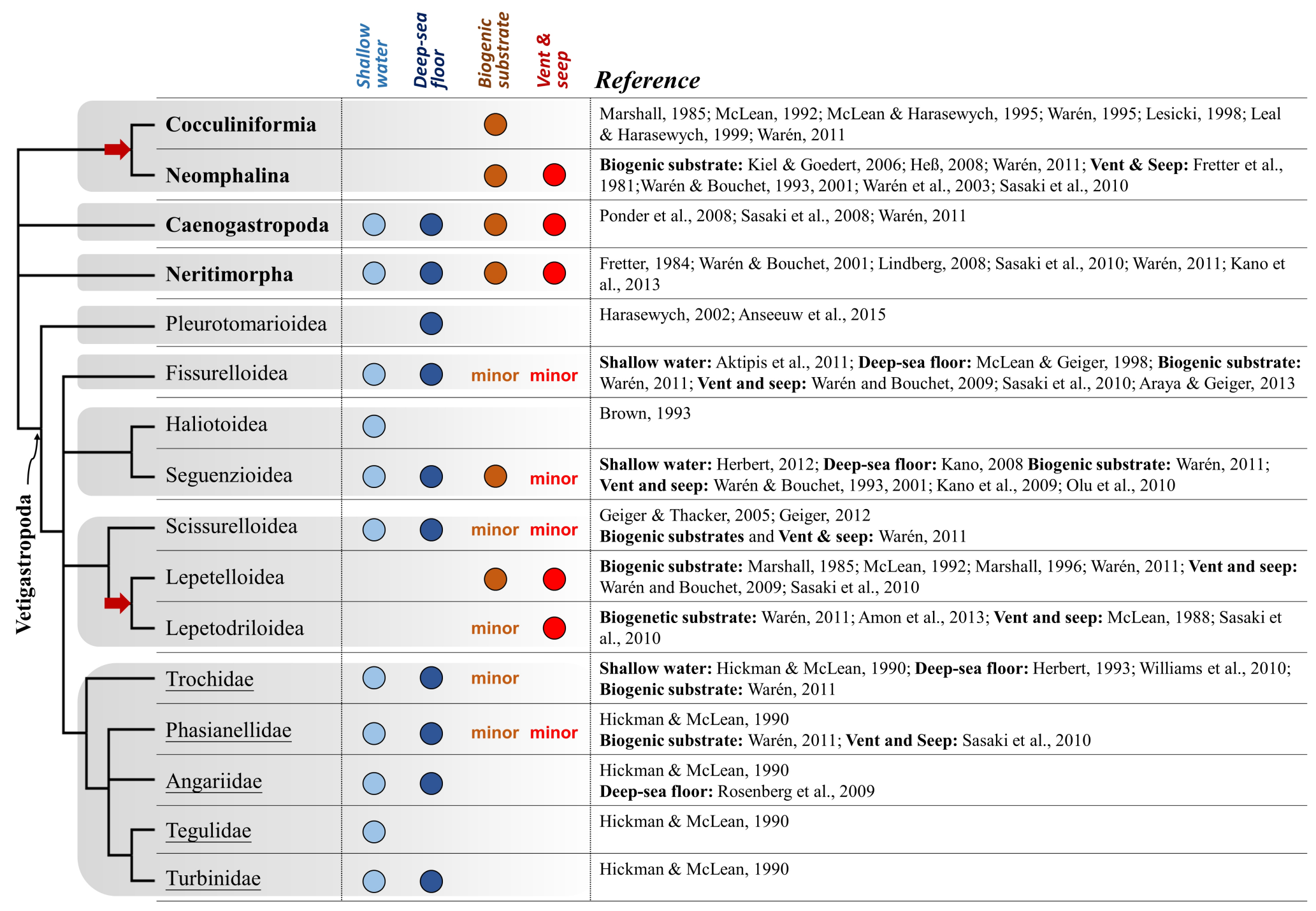


Supplementary table S1. Available mitogenomes retrieved from Genbank and analyzed in the study. Deep-sea habitats are shown in bold.

\begin{tabular}{|c|c|c|c|c|c|c|}
\hline & superfamily & family & species & accession no. & reference & habitats \\
\hline $\begin{array}{l}\text { Polyplacophora, } \\
\text { Chitonida }\end{array}$ & Mopalioidea & Mopaliidae & Katharina tunicata & U09810 & Boore and Brown, 1994 & intertidal, subtidal \\
\hline \multicolumn{7}{|l|}{ Scaphopoda, } \\
\hline Dentaliida & & Dentaliidae & Graptacme eborea & AY484748 & Boore et al., 2004 & intertidal, subtidal \\
\hline $\begin{array}{l}\text { Octopoda, } \\
\text { Octopoda }\end{array}$ & \multicolumn{5}{|c|}{ Octopoda, } & shallow water \\
\hline \multicolumn{7}{|l|}{ Bivalvia, } \\
\hline Palaeoheterodonta & Unionoidea & Unionidae & Pyganodon grandis (female) & FJ809754 & Breton et al., 2009 & fresh or brackish water \\
\hline \multirow[t]{2}{*}{ Pteriomorphia } & Mytiloidea & Mytilidae & Mytilus edulis (female) & AY484747 & Boore et al., 2004 & intertidal, subtidal \\
\hline & Pectinoidea & Pectinidae & Chlamys farreri & EF473269 & Ren et al., 2010 & intertidal, subtidal \\
\hline \multicolumn{7}{|l|}{ Gastropoda, } \\
\hline \multirow[t]{3}{*}{ Heterobranchia } & Acteonoidea & Acteonidae & Pupa strigosa & AB028237 & $\begin{array}{l}\text { Kurabayashi and } \\
\text { Ueshima, } 2000\end{array}$ & intertidal, subtidal \\
\hline & Onchidioidea & Onchidiidae & Peronia peronii & JN619346 & White et al., 2011 & intertidal \\
\hline & Siphonarioidea & Siphonariidae & Siphonaria pectinata & AY345049 & Grande et al., 2008 & intertidal \\
\hline Patellogastropoda & Lottioidea & Lottiidae & Lottia digitalis & DQ238599 & Simison et al., 2006 & intertidal, subtidal \\
\hline \multirow[t]{4}{*}{ Caenogastropoda } & Conoidea & Conidae & Conus textile & DQ862058 & $\begin{array}{l}\text { Bandyopadhyay et al., } \\
2008\end{array}$ & intertidal, subtidal \\
\hline & Muricoidea & Muricidae & Thais clavigera & DQ159954 & Jung et al. (unpublished) & intertidal, subtidal \\
\hline & Truncatelloidea & Pomatiopsidae & Tricula hortensis & EU440735 & $\begin{array}{l}\text { Zhao et al. } \\
\text { (unpublished) }\end{array}$ & freshwater \\
\hline & Vermetoidea & Vermetidae & Dendropoma maximum & HM174253 & Rawlings et al., 2010 & intertidal, subtidal \\
\hline \multirow[t]{6}{*}{ Neritimorpha } & Neritoidea & Neritidae & Theodoxus fluviatilis & KU342667 & Uribe et al., $2016 \mathrm{a}$ & freshwater \\
\hline & Neritoidea & Neritidae & Nerita versicolor & KF728890 & Arquez et al., 2014 & intertidal, subtidal \\
\hline & Neritoidea & Neritidae & Nerita melanotragus & GU810158 & $\begin{array}{l}\text { Castro and Colgan, } \\
2010\end{array}$ & intertidal, subtidal \\
\hline & Neritopsoidea & Neritopsidae & Titiscania limacina & KU342669 & Uribe et al., 2016a & intertidal, subtidal \\
\hline & Hydrocenoidea & Hydrocenidae & Georissa bangueyensis & KU342664 & Uribe et al., 2016a & terrestrial \\
\hline & Helicinoidea & Helininidae & Pleuropoma jana & KU342666 & Uribe et al., 2016a & terrestrial \\
\hline Neomphalina & Neomphaloidea & Peltospiridae & Crysomallon squamiferum & AP013032 & Nakagawa et al., 2014 & hydrothermal vent \\
\hline \multirow[t]{18}{*}{ Vetigastropoda } & Fissurelloidea & Fissurellidae & Fissurella volcano & JN790612 & Simison (unpublished) & intertidal, subtidal \\
\hline & Fissurelloidea & Fissurellidae & Diodora graeca & KT207825 & Uribe et al., 2016b & intertidal, subtidal \\
\hline & Haliotoidea & Haliotidae & Haliotis discus & EU595789 & Ren et al. (unpublished) & intertidal, subtidal \\
\hline & Haliotoidea & Haliotidae & Haliotis diversicolor & HQ832671 & Xin et al., 2011 & intertidal, subtidal \\
\hline & Haliotoidea & Haliotidae & Haliotis rubra & AY588938 & Maynard et al., 2005 & intertidal, subtidal \\
\hline & Lepetodriloidea & Lepetodrilidae & Lepetodrilus schrolli & KR297250 & Uribe et al., $2016 \mathrm{~b}$ & hydrothermal vent \\
\hline & Lepetodriloidea & Lepetodrilidae & Lepetodrilus nux & LC107880 & Nakajima et al., 2016 & hydrothermal vent \\
\hline & Seguenzioidea & Chilodontidae & Granata lyrata & KR297249 & Uribe et al., 2016b & intertidal, subtidal \\
\hline & Trochoidea & Angariidae & Angaria neglecta & KR297248 & Uribe et al., 2016b & intertidal, subtidal \\
\hline & Trochoidea & Phasianellidae & Phasianella solida & KR297251 & Uribe et al., $2016 \mathrm{~b}$ & intertidal, subtidal \\
\hline & Trochoidea & Tegulidae & Chlorostoma argyrostomum & KX298892 & Lee et al., 2016 & intertidal, subtidal \\
\hline & Trochoidea & Tegulidae & Omphalius nigerrimus & KX298895 & Lee et al., 2016 & intertidal, subtidal \\
\hline & Trochoidea & Tegulidae & Tegula brunnea & JN790613 & Simison (unpublished) & intertidal, subtidal \\
\hline & Trochoidea & Tegulidae & Tegula lividomaculata & KT207826 & Uribe et al., 2016b & intertidal, subtidal \\
\hline & Trochoidea & Turbinidae & Astralium haematragum & KX298891 & Lee et al., 2016 & intertidal, subtidal \\
\hline & Trochoidea & Turbinidae & Bolma rugosa & KT207824 & Uribe et al., 2016b & intertidal, subtidal \\
\hline & Trochoidea & Turbinidae & Lunella aff. cinerea & KF700096 & Williams et al., 2014 & intertidal, subtidal \\
\hline & Trochoidea & Turbinidae & Lunella granulata & KX298890 & Lee et al., 2016 & intertidal, subtidal \\
\hline
\end{tabular}


Supplementary table S2. Nuclear genes used in the analyses. Multiple specimens used for creating chimeric sequences of terminal taxon in data matrix are shown with an asterisk $(*)$.

\begin{tabular}{|c|c|c|c|c|c|c|c|}
\hline & superfamily & family & species & reference & $18 S$ & $28 S$ & H3 \\
\hline $\begin{array}{l}\text { Cephalopoda, } \\
\text { Coleoidea }\end{array}$ & Octopodoidea & Enteroctopodidae & Benthoctopus yaquinae & Passamaneck et al., 2004 & AY145366 & AH012195 & - \\
\hline \multicolumn{8}{|l|}{ Gastropoda, } \\
\hline \multirow[t]{6}{*}{ Neritimorpha } & Neritoidea & Neritidae & Nerita funiculata & Aktipis and Giribet, 2012 & DQ093429 & GQ160660 & DQ093497 \\
\hline & Neritoidea & Neritidae & Theodoxus fluviatilis & Aktipis and Giribet, 2012 & AF120515 & GQ160659 & - \\
\hline & Neritoidea & Phenacolepadidae & Shinkailepas briandi & this study & MK457140 & MK457137 & - \\
\hline & Neritopsoidea & Neritopsidae & Titiscania limacina & Uribe et al., 2016a & KU342683 & KU342684 & - \\
\hline & Hydrocenoidea & Hydrocenidae & Georissa bangueyensis & Uribe et al., 2016a & KU342673 & KU342674 & KU342676 \\
\hline & Helicinoidea & Helininidae & Pleuropoma jana & Uribe et al., 2016a & KU342679 & KU342680 & KU342682 \\
\hline \multirow[t]{2}{*}{ Caenogastropoda } & Littorinoidea & Littorinidae & Littorina littorea & Aktipis and Giribet, 2012 & DQ093437 & FJ977692 & DQ093507 \\
\hline & Muricoidea & Muricidae & Thais nodosa & Couto et al., 2016 & KT753639 & KT753772 & KT754133 \\
\hline \multirow[t]{4}{*}{ Cocculiniformia } & Cocculinoidea & Cocculinidae & Cocculina messingi & Aktipis and Giribet, 2012 & AF120508 & AY377696 & AY377777 \\
\hline & Cocculinoidea & Cocculinidae & Cocculina subcompressa & Aktipis and Giribet, 2012 & GQ160773 & GQ160621 & GQ160708 \\
\hline & Cocculinoidea & Cocculinidae & Cocculina sp. & Aktipis and Giribet, 2012 & GQ160774 & GQ160622 & GQ160709 \\
\hline & Cocculinoidea & Bathysciadiidae & Bathysciadium sp. & this study & MK457138 & - & - \\
\hline \multirow{3}{*}{ Neomphalina } & Neomphaloidea & Peltospiridae & Peltospira smaragdina & Aktipis and Giribet, 2012 & GQ160806 & GQ160657 & GQ160741 \\
\hline & Neomphaloidea & Melanodrymiidae & Melanodrymia aurantiaca & Aktipis and Giribet, 2012 & GQ160805 & GQ160656 & GQ160740 \\
\hline & Neomphaloidea & Neomphalidae & Cyathermia naticoides & Aktipis and Giribet, 2012 & DQ093430 & FJ977685 & DQ093498 \\
\hline \multirow[t]{17}{*}{ Vetigastropoda } & Lepetelloidea & Pyropeltidae & Pyropelta sp. & Aktipis and Giribet, 2012 & - & GQ160633 & GQ160719 \\
\hline & Lepetelloidea & Pseudococculinidae & Notocrater sp. & Aktipis and Giribet, 2012 & GQ160784 & GQ160632 & GQ160718 \\
\hline & Lepetelloidea & Pseudococculinidae & Pseudococculinidae sp. & this study & - & - & MK457142 \\
\hline & Pleurotomarioidea & Pleurotomariidae & Entemnotrochus adansonianus & Aktipis and Giribet, 2012 & AF120509 & FJ977667 & AY377774 \\
\hline & Pleurotomarioidea & Pleurotomariidae & Bayerotrochus midas* & Aktipis and Giribet, 2012 & AF120510 & FJ977668 & DQ093500 \\
\hline & Pleurotomarioidea & Pleurotomariidae & Perotrochus caledonicus & this study & MK457139 & - & MK457141 \\
\hline & Seguenzioidea & Chilodontidae & Bathymargarites symplector & Aktipis and Giribet, 2012 & DQ093433 & GQ160653 & DQ093503 \\
\hline & Seguenzioidea & Chilodontidae & Granata lyrata & Williams et al., 2008 & EU530064 & EU530010 & - \\
\hline & Fissurelloidea & Fissurellidae & Emarginula variegata & Aktipis and Giribet, 2012 & GQ160792 & GQ160640 & GQ160726 \\
\hline & Fissurelloidea & Fissurellidae & Diodora cayenensis & Aktipis and Giribet, 2012 & GQ160788 & GQ160636 & GQ160722 \\
\hline & Fissurelloidea & Fissurellidae & Puncturella sp. & Aktipis and Giribet, 2012 & FJ977641 & FJ977672 & FJ977733 \\
\hline & Scissurelloidea & Anatomidae & Anatoma sp. & Kano, 2008 & AB365302 & - & AB365260 \\
\hline & Scissurelloidea & Scissurellidae & Scissurella coronata & Williams and Ozawa, 2006 & AM048637 & AM048696 & - \\
\hline & Scissurelloidea & Scissurellidae & Sinezona confusa & Aktipis and Giribet, 2012 & AF120512 & DQ279981 & AY377773 \\
\hline & Lepetodriloidea & Lepetodrilidae & Lepetodrilus pustulosus & Aktipis and Giribet, 2012 & FJ977652 & FJ977683 & FJ977744 \\
\hline & Lepetodriloidea & Lepetodrilidae & Lepetodrilus elevatus & Aktipis and Giribet, 2012 & DQ093432 & GQ160654 & DQ093501 \\
\hline & Lepetodriloidea & Lepetodrilidae & Gorgoleptis spiralis & Aktipis and Giribet, 2012 & GQ160804 & GQ160655 & GQ160739 \\
\hline
\end{tabular}


Supplementary table S2. (Continued).

\begin{tabular}{|c|c|c|c|c|c|c|c|}
\hline & superfamily & family & species & reference & $18 S$ & $28 S$ & H3 \\
\hline \multirow{13}{*}{ Vetigastropoda } & Haliotoidea & Haliotidae & Haliotis corrugata & Aktipis and Giribet, 2012 & FJ977644 & FJ977675 & FJ977736 \\
\hline & Haliotoidea & Haliotidae & Haliotis asinina & Aktipis and Giribet, 2012 & GQ160786 & GQ160634 & GQ160720 \\
\hline & Haliotoidea & Haliotidae & Haliotis tuberculata* & Aktipis and Giribet, 2012 & GQ160787 & GQ160635 & GQ160721 \\
\hline & Trochoidea & Angariidae & Angaria formosa & Williams and Ozawa, 2006 & AM048648 & AM048708 & - \\
\hline & Trochoidea & Colloniidae & Collonia sp. & Aktipis and Giribet, 2012 & GQ160800 & GQ160649 & GQ160735 \\
\hline & Trochoidea & Phasianellidae & Phasianella ventricosa & Williams and Ozawa, 2006 & AM048659 & AM048720 & - \\
\hline & Trochoidea & Trochidae & Trochidae sp. & Aktipis and Giribet, 2012 & GQ160794 & GQ160643 & GQ160729 \\
\hline & Trochoidea & Trochidae & Stomatella planulata & Williams et al., 2008 & EU530078 & EU530029 & - \\
\hline & Trochoidea & Trochidae & Gibbula cineraria & Aktipis and Giribet, 2012 & FJ977645 & FJ977676 & FJ977737 \\
\hline & Trochoidea & Tegulidae & Microgaza sp. & Aktipis and Giribet, 2012 & GQ160797 & GQ160646 & GQ160732 \\
\hline & Trochoidea & Tegulidae & Tegula fasciata & Aktipis and Giribet, 2012 & GQ160801 & GQ160650 & GQ160736 \\
\hline & Trochoidea & Turbinidae & Turbo castanea & Aktipis and Giribet, 2012 & FJ977650 & FJ977681 & FJ977742 \\
\hline & Trochoidea & Turbinidae & Lithopoma phoebium & Aktipis and Giribet, 2012 & FJ977649 & FJ977680 & FJ977741 \\
\hline
\end{tabular}


Supplementary table S3. Mitogenomes and nuclear gene sequences used in the combined dataset. Reference data for each sequences are shown in the supplementary table 1 (mitogenomes) and 2 (nuclear genes).

\begin{tabular}{|c|c|c|c|c|c|c|}
\hline examined taxon & mitogenome used & accession num. & nuclear gene used & $18 \mathrm{~S}$ & $28 \mathrm{~S}$ & $\mathrm{H} 3$ \\
\hline Cephalopoda & Octopus vulgaris & $\mathrm{AB} 158363$ & Benthoctopus yaquinae & AY145366 & AH012195 & - \\
\hline Cocculiniformia & Cocculina subcompressa & MH837536 & Cocculina subcompressa & GQ160773 & GQ160621 & GQ160708 \\
\hline Cocculiniformia & Bathysciadiidae sp. & MH837532 & Bathysciadiidae sp. & MK457138 & - & - \\
\hline Neomphalina & Peltospira smaragdina & MH837538 & Peltospira smaragdina & GQ160806 & GQ160657 & GQ160741 \\
\hline Neomphalina & Crysomallon squamiferum & AP013032 & Cyathermia naticoides & DQ093430 & FJ977685 & DQ093498 \\
\hline Caenogastropoda & Tricula hortensis & EU440735 & Littorina littorea & DQ093437 & FJ977692 & DQ093507 \\
\hline Caenogastropoda & Thais clavigera & DQ159954 & Thais nodosa & KT753639 & KT753772 & KT754133 \\
\hline Neritimorpha & Titiscania limacina & KU342669 & Titiscania limacina & KU342683 & KU342684 & - \\
\hline Neritimorpha & Pleuropoma jana & KU342666 & Pleuropoma jana & KU342679 & KU342680 & KU342682 \\
\hline Neritimorpha & Georissa bangueyensis & KU342664 & Georissa bangueyensis & KU342673 & KU342674 & KU342676 \\
\hline Neritimorpha & Theodoxus fluviatilis & KU342667 & Theodoxus fluviatilis & AF120515 & GQ160659 & - \\
\hline Neritimorpha & Nerita versicolor & KF728890 & Nerita funiculata & DQ093429 & GQ160660 & DQ093497 \\
\hline Neritimorpha & Shinkailepas briandi & MH837541 & Shinkailepas briandi & MK457140 & MK457137 & - \\
\hline Pleurotomarioidea & Perotrochus caledonicus & MH837539 & Perotrochus caledonicus & MK457139 & - & MK457141 \\
\hline Pleurotomarioidea & Bayerotrochus teramachii & MH837533 & Bayerotrochus midas & AF120510 & FJ977668 & DQ093500 \\
\hline Fissurelloidea & Variegemarginula punctata & KX298889 & Emarginula variegata & GQ160792 & GQ160640 & GQ160726 \\
\hline Fissurelloidea & Diodora graeca & KT207825 & Diodora cayenensis & GQ160788 & GQ160636 & GQ160722 \\
\hline Haliotoidea & Haliotis rubra & AY588938 & Haliotis corrugata & FJ977644 & FJ977675 & FJ977736 \\
\hline Haliotoidea & Haliotis discus & EU595789 & Haliotis asinina & GQ160786 & GQ160634 & GQ160720 \\
\hline Seguenzioidea & Granata lyrata & KR297249 & Granata lyrata & EU530064 & EU530010 & - \\
\hline Seguenzioidea & Calliotropis micraulax & MH837534 & Bathymargarites symplector & DQ093433 & GQ160653 & DQ093503 \\
\hline Scissurelloidea & Anatoma sp. & MH837531 & Anatoma sp. & AB365302 & - & $\mathrm{AB} 365260$ \\
\hline Lepetelloidea & Pseudococculinidae sp. & MH837540 & Pseudococculinidae sp. & - & - & this study \\
\hline Lepetodriloidea & Lepetodrilus guaymasensis & MH837537 & Lepetodrilus pustulosus & FJ977652 & FJ977683 & FJ977744 \\
\hline Lepetodriloidea & Lepetodrilus schrolli & KR297250 & Lepetodrilus elevatus & DQ093432 & GQ160654 & DQ093501 \\
\hline Phasianellidae & Phasianella solida & KR297251 & Collonia sp. & GQ160800 & GQ160649 & GQ160735 \\
\hline Phasianellidae & Phasianella australis & KX298888 & Phasianella ventricosa & AM048659 & AM048720 & - \\
\hline Angariidae & Angaria delphinus & KX298893 & Angaria formosa & AM048648 & AM048708 & - \\
\hline Trochidae & Stomatella planulata & KX298894 & Stomatella planulata & EU530078 & EU530029 & - \\
\hline Tegulidae & Tegula brunnea & JN790613 & Tegula fasciata & GQ160801 & GQ160650 & GQ160736 \\
\hline Turbinidae & Lunella granulata & KX298890 & Turbo castanea & FJ977650 & FJ977681 & FJ977742 \\
\hline Turbinidae & Astralium haematragum & KX298891 & Lithopoma phoebium & FJ977649 & FJ977680 & FJ977741 \\
\hline
\end{tabular}


Supplementary table S4. Partitions and best-fit models in RAxML and MrBayes given by PartitionFinder v.1.1.0.

\section{Partitions and best-fit models in RAxML}

Big $m$ t dataset

protein-coding genes $1^{\text {st }}$ codon protein-coding genes $2^{\text {nd }}$ codon protein-coding genes $3^{\text {rd }}$ codon

$12 S+16 S$

$$
\text { Small mt dataset }
$$

protein-coding genes $1^{\text {st }}$ codon

protein-coding genes $2^{\text {nd }}$ codon

protein-coding genes $3^{\text {rd }}$ codon

$12 S+16 S$

\section{Nuclear dataset}

\section{$18 \mathrm{~S}$}

$28 S$

H3 $1^{\text {st }}$ codon

$H 32^{\text {nd }}$ codon

H3 $3^{\text {rd }}$ codon

\section{Partitions and best-fit models in MrBayes}

Big $m$ t dataset

protein-coding genes $1^{\text {st }}$ codon

Model used

$\mathrm{GTR}+\mathrm{I}+\mathrm{G}$

$\mathrm{GTR}+\mathrm{I}+\mathrm{G}$

$\mathrm{GTR}+\mathrm{I}+\mathrm{G}$

$\mathrm{GTR}+\mathrm{I}+\mathrm{G}$

protein-coding genes $2^{\text {nd }}$ codon

protein-coding genes $3^{\text {rd }}$ codon

$12 S+16 S$

$\mathrm{GTR}+\mathrm{I}+\mathrm{G}$

$\mathrm{GTR}+\mathrm{I}+\mathrm{G}$

$\mathrm{F} 81+\mathrm{I}+\mathrm{G}$

$\mathrm{GTR}+\mathrm{I}+\mathrm{G}$

Small mt dataset

GTR + I+G
GTR + I+G
GTR + I + G
GTR + I+G

protein-coding genes $1^{\text {st }}$ codon

$\mathrm{GTR}+\mathrm{I}+\mathrm{G}$

protein-coding genes $2^{\text {nd }}$ codon

$\mathrm{GTR}+\mathrm{I}+\mathrm{G}$

protein-coding genes $3^{\text {rd }}$ codon

$\mathrm{F} 81+\mathrm{I}+\mathrm{G}$

$12 S+16 S$

$\mathrm{GTR}+\mathrm{I}+\mathrm{G}$

\section{Nuclear dataset}

$\mathrm{GTR}+\mathrm{I}+\mathrm{G}$

$18 \mathrm{~S}$

$\mathrm{GTR}+\mathrm{I}+\mathrm{G} \quad 28 \mathrm{~S}$

H3 $1^{\text {st }}$ codon

$\mathrm{K} 80+\mathrm{I}+\mathrm{G}$

$\mathrm{GTR}+\mathrm{I}+\mathrm{G}$

H3 $2^{\text {nd }}$ codon

$\mathrm{GTR}+\mathrm{I}+\mathrm{G}$

$\mathrm{GTR}+\mathrm{I}+\mathrm{G}$

H3 $3^{\text {rd }}$ codon

$\mathrm{GTR}+\mathrm{I}+\mathrm{G}$

$\mathrm{JC}+\mathrm{I}+\mathrm{G}$

$\mathrm{GTR}+\mathrm{I}+\mathrm{G}$

$\mathrm{GTR}+\mathrm{I}+\mathrm{G}$ 
Hypothetical ancestral gene order of gastropods (Stöger and Schrödl, 2013)

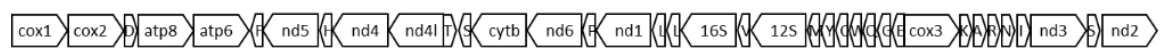

\section{Neritimorpha}

Shinkailepas briandi

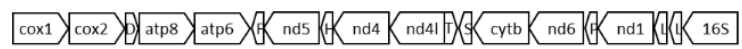

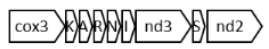

\section{Cocculiniformia}

Coccocrater sp.

Cocculina subcompressa

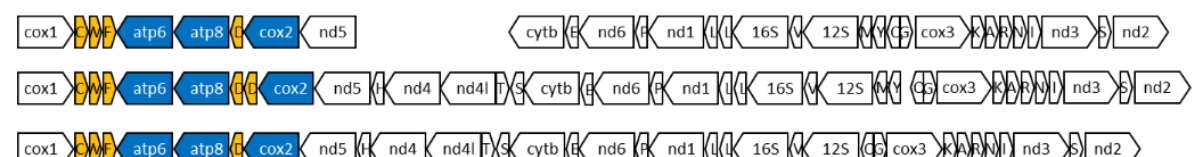

Bathysciadiidae sp.

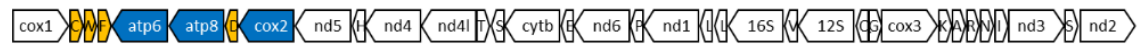

\section{Neomphalina}

Peltospira smaragdina

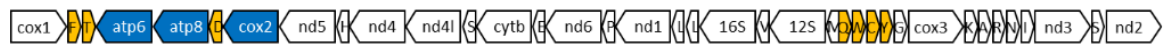

\section{Vetigastropoda \\ Bayerotrochus teramachii \\ Perotrochus caledonicus \\ Calliotropis micraulax \\ Anatoma sp.

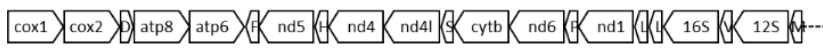

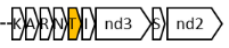

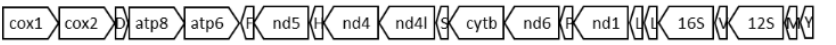 \\ $\mathrm{nd3} 3 \mathrm{nd2}$

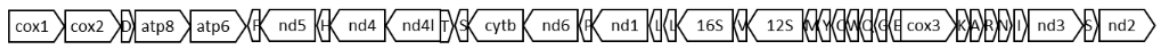

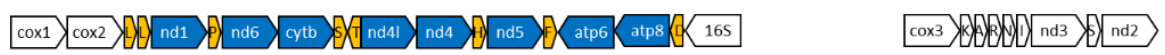 \\ Lepetodrilus guaymasensis

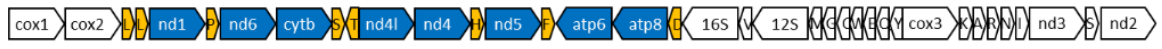 \\ Pseudococculinidae sp.

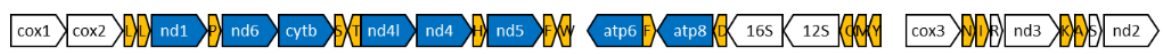

Supplementary figure S1. Gene order of the newly reconstructed mitogenomes of deep-sea gastropods. White gaps separate the contigs obtained from NGS reads, these regions might have the missing genes (see text). The dashed line represents there was no gap in LR-PCR. Protein-coding genes with blue and tRNAs with yellow show different arrangements/directions to the hypothetical ancestral gastropod gene order. Genes without color correspond to the hypothetical ancestral gastropod gene order. 
(a)

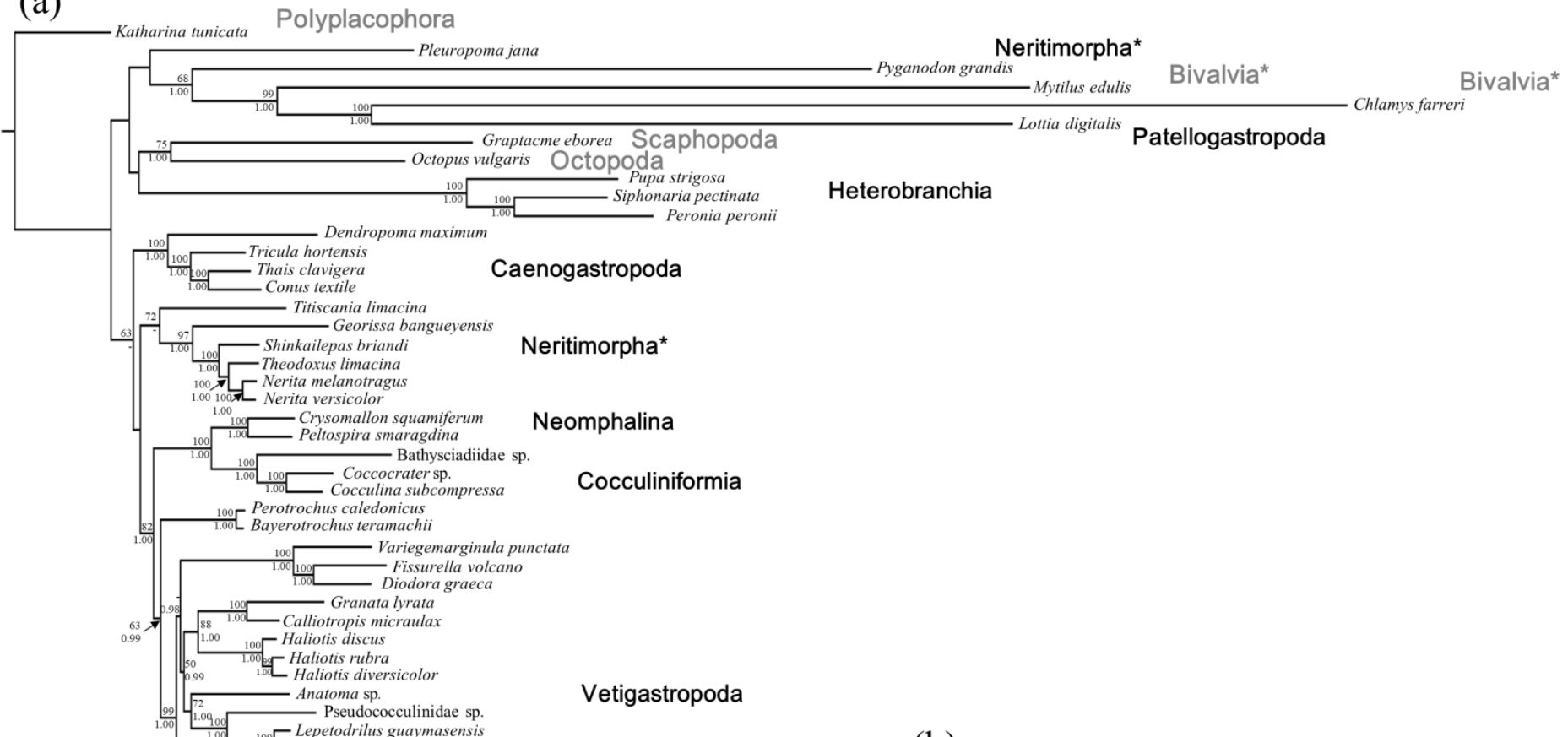

(b)

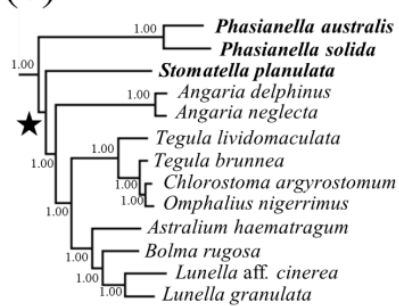

Supplementary figure S2. Phylogenetic relationships within Gastropoda inferred from the large mt dataset using partitioned ML and BI methods. (a) ML tree based on 10,393 bp nucleotide sequences combined from 13 protein-coding genes and two rRNA genes. Nodal support is shown as BP in percentage and PP; (b) partial BI tree based on the same dataset as in (a). Asterisk in (b) indicates the difference topology compare to the ML tree (a), where $\mathrm{PP}<0.8$. 


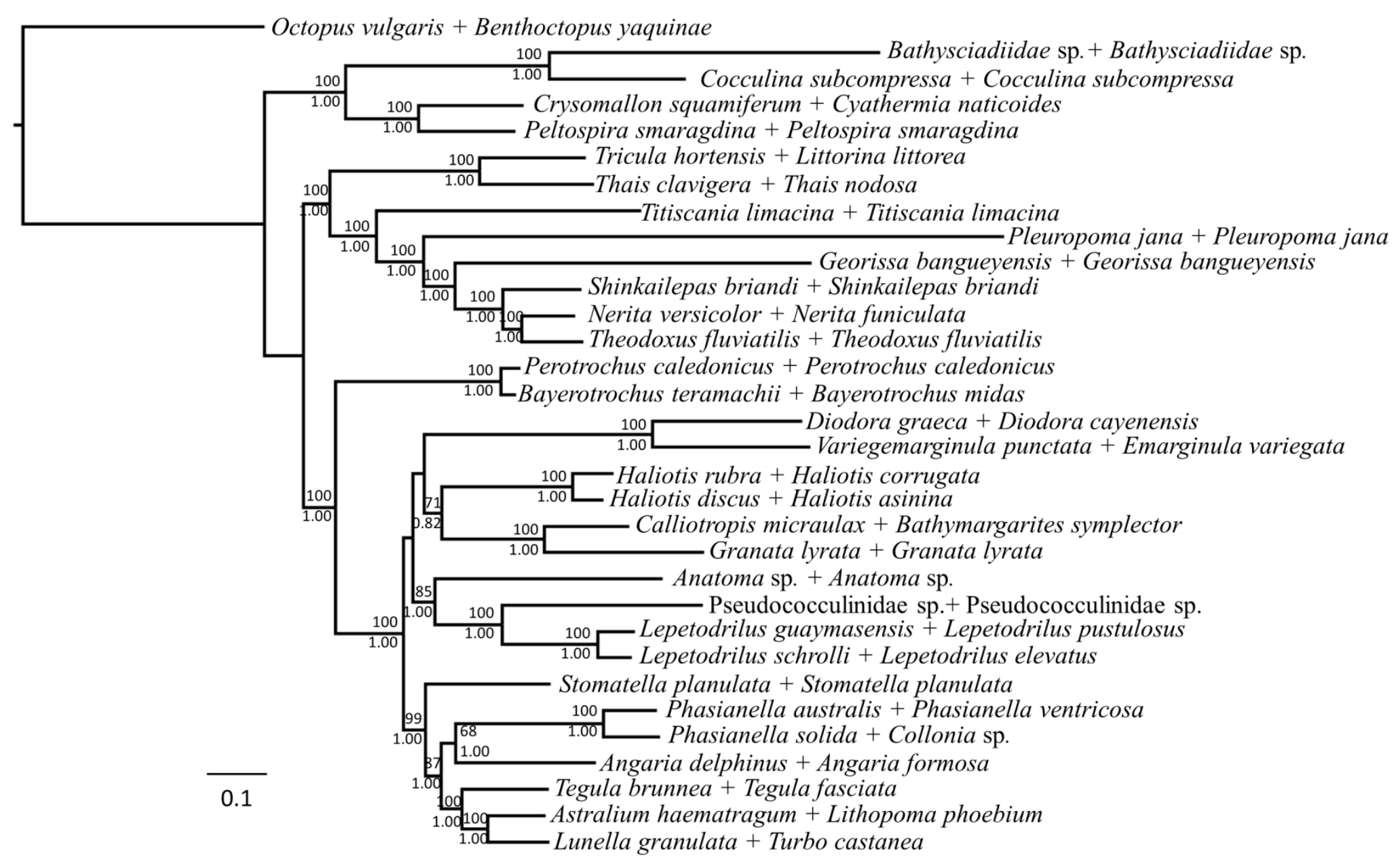

Supplementary figure S3. Partitioned maximum-likelihood (ML) tree based on 14,442 bp nucleotide sequences combined from 13 mitochondrial protein-coding genes, 2 ribosomal RNA genes, and nuclear genes including $18 \mathrm{~S}, 28 \mathrm{~S}$, and $H 3$ (combined dataset). This phylogenetic tree is identical to figure 3 without collapsing the nodes. The format of taxon names is: mitogenome used taxon + nuclear genes used taxon. Nodal supports are shown as bootstrap (BP) values in percentage / posterior probabilities (PP). Values below 50\% in BP and 0.8 in PP are not shown. 